\title{
Redox-Switchable Allosteric Effects in Molecular Clusters
}

Benjamin S. Mitchell ${ }^{1}$, Sebastian M. Krajewski, ${ }^{1}$ Jonathan A. Kephart, ${ }^{1}$ Dylan Rogers, ${ }^{1}$ Werner Kaminsky ${ }^{1}$, Alexandra Velian $^{1 *}$

\section{Table of Contents}

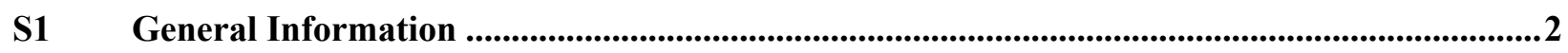

S2 Synthetic Details and Characterization of Products .......................................................................3

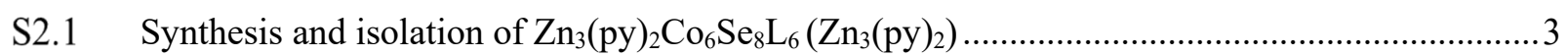

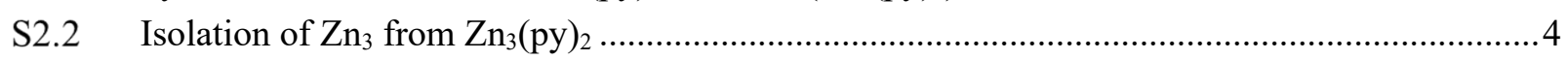

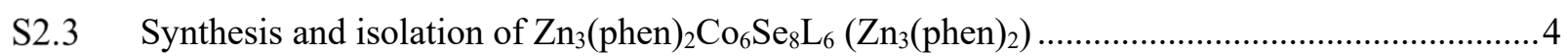

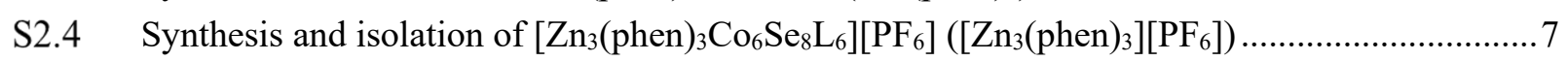

S2.5 Synthesis and isolation of $\mathrm{Zn}_{3}($ bipy $) \mathrm{Co}_{6} \mathrm{Se}_{8} \mathrm{~L}_{6}$ (1-bipy) .......................................................

S2.6 Formation and single crystal growth of $\mathrm{Zn}_{3}(\mathrm{tpphz}) \mathrm{Co}_{6} \mathrm{Se}_{8} \mathrm{~L}_{6}$ (1-tpphz) ………………..........

S2.7 Synthesis and Isolation of $\left[\mathrm{Zn}_{3}(\mathrm{bpy})_{1.5} \mathrm{Co}_{6} \mathrm{Se}_{8} \mathrm{~L}_{6}\right]\left[\mathrm{PF}_{6}\right](2$-bipy)........................................... 10

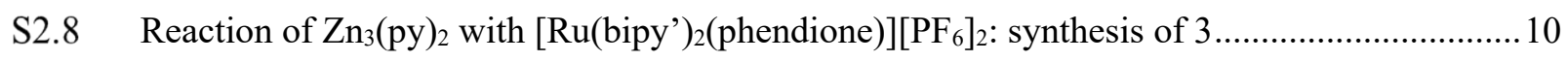

S3 Electrochemistry .......................................................................................................................13

S4 X-ray Diffraction Studies....................................................................................................15

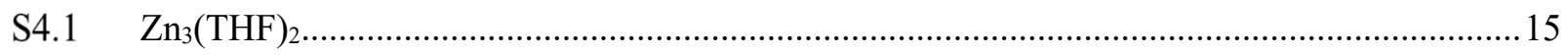

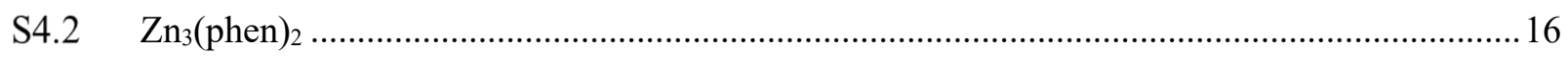

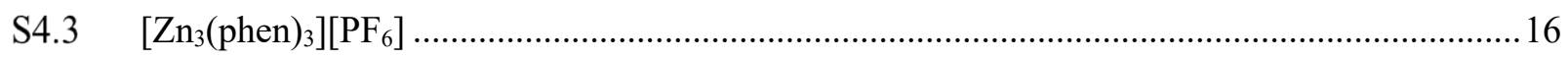

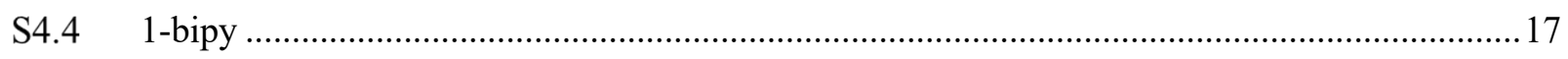

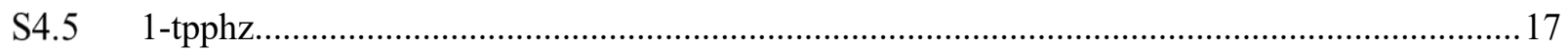

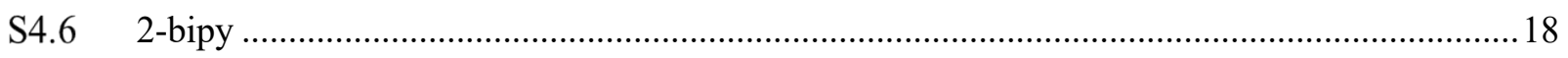

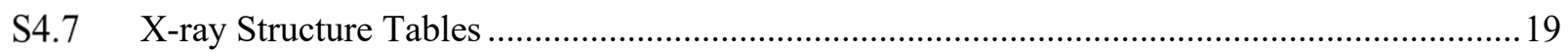

S5 References ............................................................................................................................ 


\section{S1 General Information}

No unexpected or unusually high safety hazards were encountered during the experimental work reported in here.

The syntheses were conducted under a dinitrogen atmosphere using standard Schlenk or glovebox techniques (LC Technology Solutions glovebox equipped with a freezer set to $-35^{\circ} \mathrm{C}$ ). The glassware was dried at $160{ }^{\circ} \mathrm{C}$ for a minimum of $12 \mathrm{~h}$ and cooled in an evacuated antechamber prior to use in the glovebox.

Solvents were purchased from Fischer Scientific and degassed, dried and purified using solvent purification columns housed in a stainless-steel cabinet and dispensed by a stainless-steel Schlenk line manufactured by JC Meyer Solvent Systems. Tetrahydrofuran (THF), diethyl ether, acetonitrile, and methylene chloride (DCM) are passed through two packed columns of neutral alumina. In the cases of $n$-pentane and toluene, one of the columns is packed with alumina and the other with Q5 reactant, a copper(II) oxide oxygen scavenger. All solvents were passed through an in-line, $2 \mu \mathrm{m}$ filter, then stored over activated $3 \AA$ molecular sieves in the glovebox for a minimum of $72 \mathrm{~h}$ before use. $3 \AA$ molecular sieves were purchased from Sigma Aldrich and activated under vacuum at $300{ }^{\circ} \mathrm{C}$ for $48 \mathrm{~h}$.

Deuterated solvents $\left(\mathrm{CDCl}_{3}, \mathrm{C}_{6} \mathrm{D}_{6}, \mathrm{CD}_{2} \mathrm{Cl}_{2}, \mathrm{CD}_{3} \mathrm{CN}\right)$ were purchased from Sigma Aldrich and stored over activated $3 \AA$ molecular sieves in the glovebox for a minimum of $72 \mathrm{~h}$ prior to use. $\mathrm{Li}_{6}(\mathrm{py})_{6} \mathrm{Co}_{6} \mathrm{Se}_{8} \mathrm{~L}_{6}$ was prepared via reported literature methods. ${ }^{1} \mathrm{ZnCl}_{2}(99.99 \%-\mathrm{Zn}$, PURATREM) was purchased from Strem Chemicals, Inc. and used as received without further purification. 1,10-phenanthroline (99\%, anhydrous) was purchased from Sigma Aldrich and used without further purification. Ferrocenium hexafluorophosphate was purchased from Sigma Aldrich and recrystallized from dry acetone and diethyl ether prior to use. Tetrapyrido[3,2-a:2',3'-c:3", $\left.2^{\prime \prime}-\mathrm{h}: 2^{\prime \prime \prime}, 3^{\prime \prime \prime}-\mathrm{j}\right]$ phenazine was prepared using reported literature methods. ${ }^{2}$ Tetra( $n$-butyl)ammonium hexafluorophosphate (98\%) was purchased from Sigma Aldrich; prior to use it was recrystallized from ethanol three times, and brought to constant mass under reduced pressure at $110{ }^{\circ} \mathrm{C}$ for $24 \mathrm{~h}$. $\left[\mathrm{Ru}(\mathrm{bpy})_{2}(\right.$ phendione $\left.)\right]\left[\mathrm{PF}_{6}\right]_{2}$ was prepared using reported literature methods. ${ }^{3}$

Samples were prepared for elemental analysis by first crushing crystalline material into a powder, bringing it to constant mass under reduced pressure (ca. $12 \mathrm{~h}$ ). Co, Se, P elemental analysis was conducted using a Perkin-Elmer Nexion 200B inductively-coupled plasma mass spectrometer (ICP-MS). Prior to ICP-MS analysis, samples were digested in neat nitric acid (Fisher Scientific, ICP-MS grade) at $50{ }^{\circ} \mathrm{C}$.

UV-vis- $n$ IR absorption spectra were acquired using a Varian Cary 5000 UV-Vis- $n$ IR spectrometer using $n$ IR quartz cuvettes (Spectrocell Inc., $10 \mathrm{~mm}$ path length, 220-3500 nm spectral window). Emission spectra were acquired using a Horiba FluoroMax-4, using fluorometer optical borosilicate VIS cuvettes (Spectrocell Inc., $10 \mathrm{~mm}$ path length, 340-2000 nm spectral window).

NMR spectra were acquired at $25{ }^{\circ} \mathrm{C}$ on Bruker 300,500 , or $700 \mathrm{MHz}$ spectrometers. ${ }^{1} \mathrm{H}$ and ${ }^{13} \mathrm{C}$ NMR spectra were referenced to residual deuterated solvent peaks. ${ }^{31} \mathrm{P}$ and ${ }^{19} \mathrm{~F}$ NMR spectra were externally referenced to phosphoric acid and $\mathrm{CCl}_{3} \mathrm{~F}$, respectively.

Cyclic voltammetry was conducted using a Gamry Interface 1010B potentiostat. A three-electrode cell setup was used with a glassy carbon disk working electrode, a platinum wire counter electrode, and a silverwire pseudo-reference electrode. A three-electrode cell was also used for solid-state electrochemical measurements; in this instance, the analyte was dropcasted onto a carbon fiber paper electrode $(1 \times 1 \mathrm{~cm}$, Spectracarb 2050A-1550) from a suspension of toluene. All potentials were referenced to the $\mathrm{Fc} / \mathrm{Fc}^{+}$redox couple by adding a small amount of ferrocene $(\mathrm{Fc})$ after each measurement. All electrochemical measurements were conducted under a dinitrogen atmosphere, at $25^{\circ} \mathrm{C}$. 


\section{S2 Synthetic Details and Characterization of Products}

\section{S2.1 Synthesis and isolation of $\mathrm{Zn}_{3}(\mathrm{py})_{2} \mathrm{Co}_{6} \mathrm{Se}_{8} \mathrm{~L}_{6}\left(\mathrm{Zn}_{3}(\mathrm{py})_{2}\right)$}

A $100 \mathrm{~mL}$ Schlenk flask equipped with a 1-inch magnetic stir bar was loaded with $\mathrm{Li}_{6}\left(\right.$ py) ${ }_{6} \mathrm{Co}_{6} \mathrm{Se}_{8} \mathrm{~L}_{6}(1.269$ $\mathrm{g}, 0.391 \mathrm{mmol}, 1.0$ equiv) and toluene $(60 \mathrm{~mL})$, and the resulting mixture was partially frozen using the glovebox cold-well. Upon thawing, $\mathrm{ZnCl}_{2}(0.176 \mathrm{~g}, 1.29 \mathrm{mmol}, 3.3$ equiv) dissolved in THF (6 mL) was added dropwise over the course of 2 minutes to the stirring mixture. The reaction flask was then degassed, sealed, and removed from the glovebox. The dark-red reaction mixture was then stirred at $60{ }^{\circ} \mathrm{C}$ for $20 \mathrm{~h}$. Volatiles were removed under reduced pressure. The residue was first triturated with diethyl ether $(3 \times 5$ $\mathrm{mL})$, extracted in DCM $(50 \mathrm{~mL})$ and then passed through a plug of Celite on a fritted-glass funnel. The filtrate was placed under reduced pressure yielding a dark colored, black looking solid, which was slurried in acetonitrile $(100 \mathrm{~mL})$ for $1 \mathrm{~h}$, and then recollected on a fine-porosity fritted-glass filter. The isolated solids were washed with a second portion of acetonitrile $(30 \mathrm{~mL})$ to yield $\mathbf{Z n}_{\mathbf{3}}(\mathrm{py})_{2}$ as an analytically pure, black, microcrystalline solid $(0.811 \mathrm{~g}, 0.263 \mathrm{mmol}, 67 \%)$. ${ }^{1} \mathbf{H}$ NMR $\left(\mathrm{C}_{6} \mathrm{D}_{6}, 300 \mathrm{MHz}\right) \delta: 8.38$ (br, $4 \mathrm{H}$, py$\left.\mathrm{N}(\mathrm{CH})_{2}(\mathrm{CH})_{2} \mathrm{CH}\right), 7.71\left(\mathrm{~m}, 24 \mathrm{H}, \mathrm{PPh}_{2} \mathrm{Ar} \boldsymbol{H}\right), 7.08\left(\mathrm{~m}, 18 \mathrm{H}, \mathrm{PPh}_{2} \mathrm{Ar} \boldsymbol{H}\right), 6.98$ (m, $\left.6 \mathrm{H}, \mathrm{PPh}_{2} \mathrm{Ar} \boldsymbol{H}\right), 6.76$ (br, $4 \mathrm{H}$, py- $\left.\mathrm{N}(\mathrm{CH})_{2}(\mathrm{CH})_{2} \mathrm{CH}\right), 6.71(\mathrm{~d}, 12 \mathrm{H}, J=8.0 \mathrm{~Hz}$, tolyl $o-\mathrm{Ar} \boldsymbol{H}), 6.51(\mathrm{~d}, 12 \mathrm{H}, J=8.0 \mathrm{~Hz}$, tolyl $m$ $\mathrm{Ar} \boldsymbol{H}), 1.80$ (s, $18 \mathrm{H}$, 4-tolyl-CH$\left.{ }_{3}\right)$ ppm. ${ }^{1} \mathbf{H}$ NMR $\left(\mathrm{CD}_{2} \mathrm{Cl}_{2}, 500 \mathrm{MHz}\right) \delta: 7.22-7.45$ (m, $\left.60 \mathrm{H}, \mathrm{Ar} \boldsymbol{H}\right), 6.75$ $(\mathrm{d}, 12 \mathrm{H}, J=8.2 \mathrm{~Hz}$, tolyl $o$-ArH $), 6.25(\mathrm{~d}, 12 \mathrm{H}, J=8.2 \mathrm{~Hz}$, tolyl $m$-ArH $), 2.04$ (s, $18 \mathrm{H}, 4$-tolyl-CH$).{ }^{13} \mathbf{C}$ NMR $\left(\mathrm{CD}_{2} \mathrm{Cl}_{2}, 125 \mathrm{MHz}\right) \delta$ : $147.0(\mathrm{~d}, 15.0 \mathrm{~Hz}, i$-tolyl), 142.0 (d, $J=40 \mathrm{~Hz}, i$-PPh $), 139.6$ (d, $J=40 \mathrm{~Hz}$, $\left.i-\mathrm{PPh}_{2}\right), 132.6(\mathrm{~d}, J=10.0 \mathrm{~Hz}, \mathrm{PPh} \boldsymbol{C H}), 132.1(\mathrm{~d}, J=10.0 \mathrm{~Hz}, \mathrm{PPh} \boldsymbol{C H}), 129.2(\mathrm{~s}, \mathrm{PPh} p-\boldsymbol{C H}), 128.9(\mathrm{~s}$, tolyl $m-(\boldsymbol{C H})_{2}, 128.7(\mathrm{~s}, \mathrm{PPh} p-\boldsymbol{C H}), 128.5\left(\mathrm{~s}\right.$, tolyl $\left.\boldsymbol{C} \mathrm{CH}_{3}\right), 127.6(\mathrm{~d}, J=10.0 \mathrm{~Hz}, \mathrm{PPh} \boldsymbol{C H}), 127.3$ $(\mathrm{d}, J=10.0 \mathrm{~Hz}, \mathrm{PPh} \boldsymbol{C H}), 122.9\left(\mathrm{~d}, J=10.0 \mathrm{~Hz}\right.$, tolyl $\left.o-(\boldsymbol{C H})_{2}\right), 20.4\left(\mathrm{~s}, 4\right.$-tolyl- $\left.\boldsymbol{C H}_{3}\right)$ ppm. ${ }^{31} \mathbf{P}$ NMR $\left(\mathrm{C}_{6} \mathrm{D}_{6}\right.$, $283 \mathrm{MHz}): \delta+86.9\left(v_{1 / 2}=333 \mathrm{~Hz}\right) \mathrm{ppm}$. UV-vis: Figure $\mathrm{S} 10$. Elemental analysis found (calc.) for $\mathbf{Z n}_{3}(\mathrm{py})_{2}$ (Formula: $\mathrm{C}_{124} \mathrm{H}_{112} \mathrm{Co}_{6} \mathrm{~N}_{8} \mathrm{P}_{6} \mathrm{Se}_{8} \mathrm{Zn}_{3}$ ): Co 11.66 (11.47), Se 20.74 (20.50), P 5.86 (6.03).

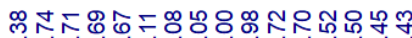

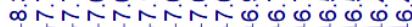

$\mathbf{Z n}_{\mathbf{3}}(\mathrm{py})_{2}$

${ }^{1} \mathrm{H}$ NMR in $\mathrm{C}_{6} \mathrm{D}_{6}(300 \mathrm{MHz})$

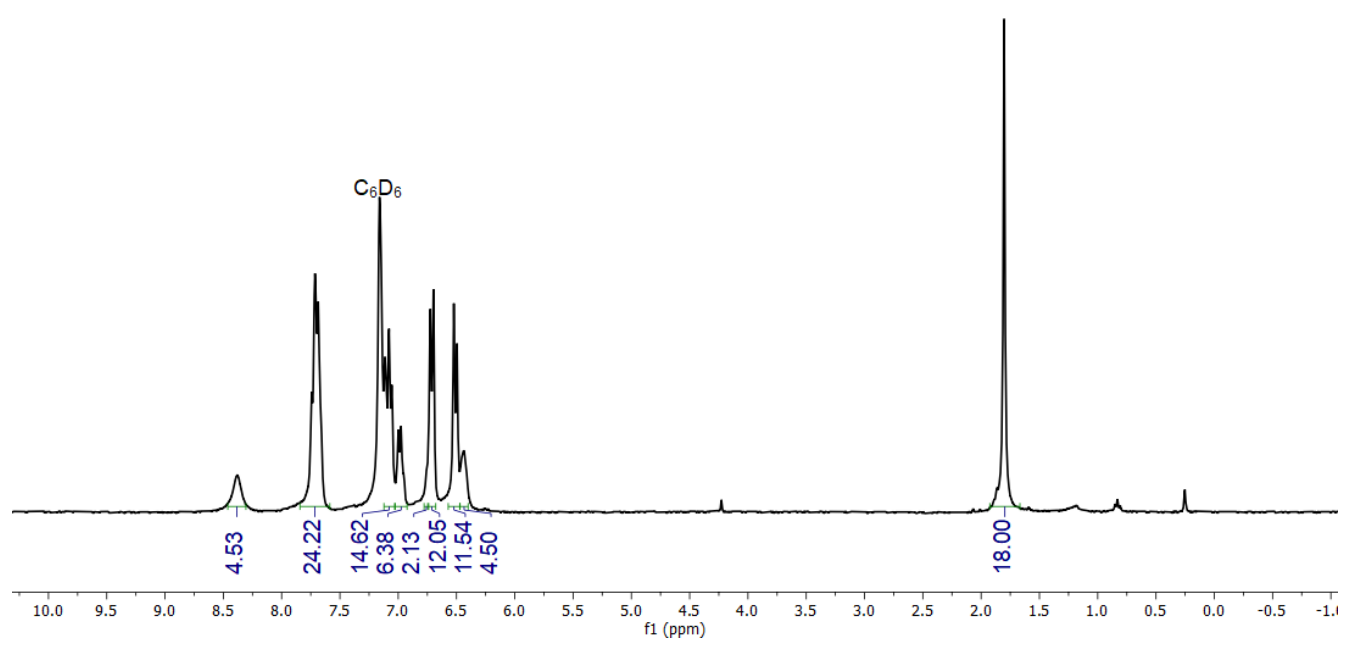

Figure S1. ${ }^{1} \mathrm{H}$ NMR $\left(\mathrm{C}_{6} \mathrm{D}_{6}, 25{ }^{\circ} \mathrm{C}, 700 \mathrm{MHz}\right)$ spectrum of $\mathbf{Z n}_{3}(\mathrm{py})_{2}$. 


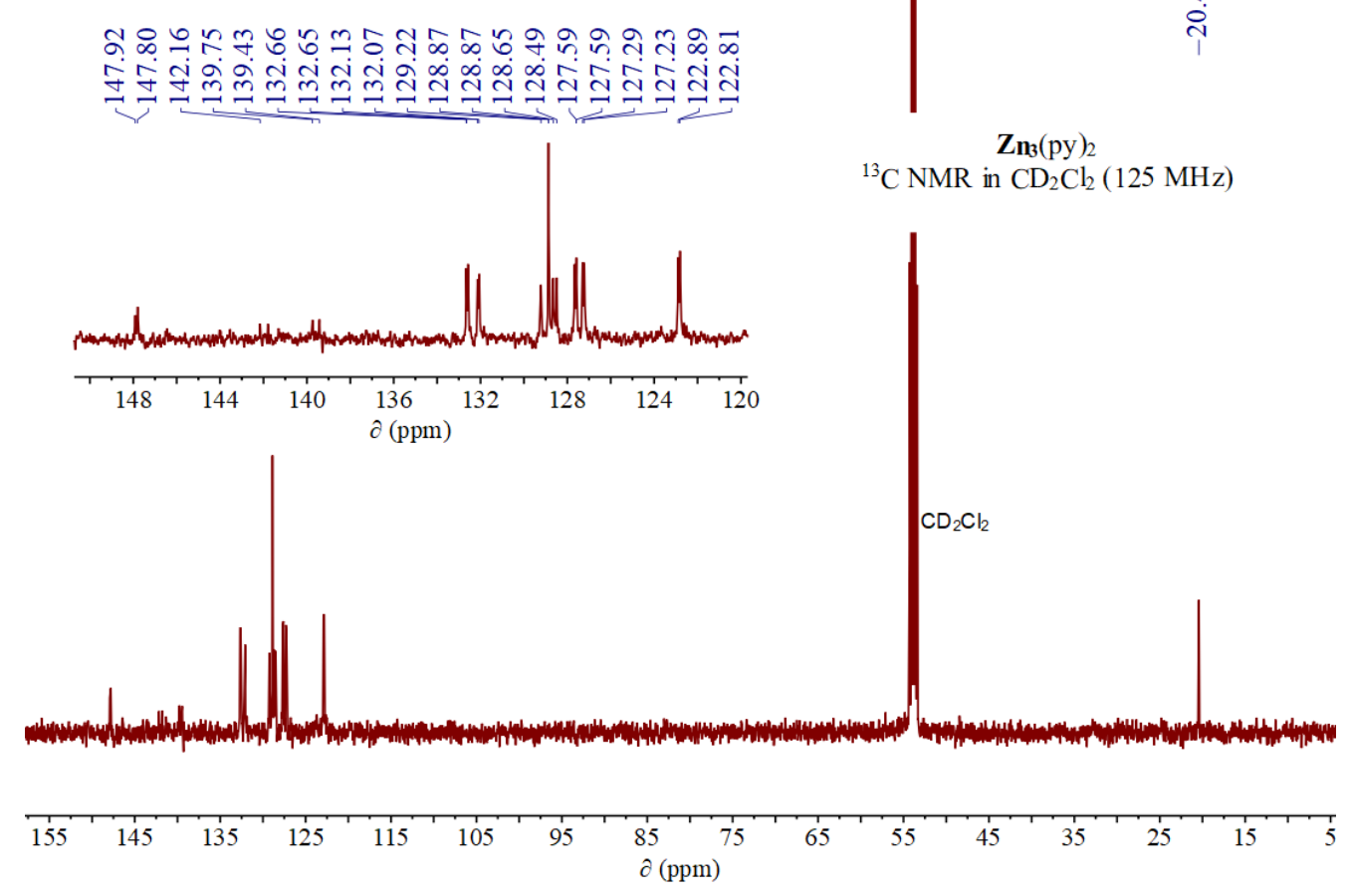

Figure S2. ${ }^{13} \mathrm{C}$ NMR $\left(\mathrm{CD}_{2} \mathrm{Cl}_{2}, 25{ }^{\circ} \mathrm{C}, 125 \mathrm{MHz}\right)$ spectrum of $\mathbf{Z n}_{3}(\text { py })_{2}$.

\section{S2.2 Isolation of $\mathrm{Zn}_{3}$ from $\mathrm{Zn}_{3}(\mathrm{py})_{2}$}

Removal of the coordinated pyridine ligands in $\mathbf{Z n}_{3}(\mathrm{py})_{2}$ was accomplished by extensive trituration with diethyl ether. $\mathbf{Z n}_{3}$ (py $)_{2}$ was first slurried in diethyl ether under vigorous stirring for 3-8 hours, then placed under reduced pressure while being heated at $80^{\circ} \mathrm{C}$ for $3-12$ hours. This process was repeated three times to ensure the coordinated pyridine was completely removed from the nanocluster. ${ }^{1} \mathbf{H}$ NMR $\left(\mathrm{C}_{6} \mathrm{D}_{6}, 300\right.$

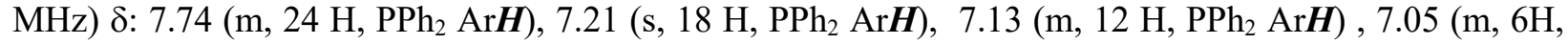
$\left.\mathrm{PPh}_{2} \mathrm{Ar} \boldsymbol{H}\right), 6.63(\mathrm{~d}, 12 \mathrm{H}, J=8.1 \mathrm{~Hz}$, tolyl $o-\operatorname{Ar} \boldsymbol{H}), 6.51(\mathrm{~d}, 12 \mathrm{H}, J=8.1 \mathrm{~Hz}$, tolyl $m-\operatorname{Ar} \boldsymbol{H}), 1.81(\mathrm{~s}, 18 \mathrm{H}$, 4-tolyl- $\left.\mathrm{CH}_{3}\right) \mathrm{ppm}$.

\section{S2.3 Synthesis and isolation of $\mathrm{Zn}_{3}(\text { phen })_{2} \mathrm{Co}_{6} \mathrm{Se}_{8} \mathbf{L}_{6}\left(\mathbf{Z n}_{3}(\text { phen })_{2}\right)$}

$\mathbf{Z n}_{3}$ (py) 2 (500 mg, $0.162 \mathrm{mmol}, 1.0$ equiv) was charged into a $20 \mathrm{~mL}$ scintillation vial and dissolved in DCM (10 mL). 1,10-Phenanthroline (93 mg, $0.513 \mathrm{mmol}, 3.15$ equiv) was dissolved separately in DCM (2 $\mathrm{mL}$ ) and added to the $\mathbf{Z n}_{\mathbf{3}}$ (py) $)_{2}$ solution with stirring. The reaction was stirred at room temperature for 30 minutes. The reaction mixture was concentrated under reduced pressure to half of its original volume, layered with $n$-pentane $(\sim 15 \mathrm{~mL})$, and placed in the glovebox freezer overnight. The dark, black looking precipitate was isolated via vacuum filtration through a fine porosity glass fritted funnel and identified as $\mathbf{Z n}_{3}$ (phen) $)_{2}$ (437 mg, $0.133 \mathrm{mmol}, 82 \%$ yield). The product showed very poor solubility in $\mathrm{C}_{6} \mathrm{D}_{6}$ and $\mathrm{CD}_{3} \mathrm{CN}$, however it was very soluble in $\mathrm{CD}_{2} \mathrm{Cl}_{2}$. Upon dissolution in pyridine- $d_{5}$ the phenanthroline ligands dissociate from the cluster. ${ }^{1} \mathrm{H}$ NMR spectrum reveals the formation of $\mathbf{Z n}_{3}(\mathrm{py})_{\mathrm{x}}$ cluster and uncoordinated 1,10-phenanthroline (Figure S5). ${ }^{1} \mathbf{H}$ NMR $\left(\mathrm{CD}_{2} \mathrm{Cl}_{2}, 25^{\circ} \mathrm{C}, 300 \mathrm{MHz}\right) \delta: 8.73$ (s, br, $4 \mathrm{H}, v_{1 / 2}=23.0 \mathrm{~Hz}$, phen-NCHCH), 8.10 (s, br, $4 \mathrm{H}, \boldsymbol{v}_{1 / 2}=18.1 \mathrm{~Hz}$, phen-NCHCH), 7.64 (s, $6 \mathrm{H}$,), 7.32 (s, br), 7.23 (s, br), 7.18 (s, br), 7.04 (s, br), 5.86 (s, br, $24 \mathrm{H}, v_{1 / 2}=110.1 \mathrm{~Hz}$, 4-tolyl-ArH), 1.74 (s, br, $18 \mathrm{H}, v_{1 / 2}=46.3 \mathrm{~Hz}$, 4tolyl-CH$\left.)_{3}\right)$ ppm. ${ }^{13} \mathbf{C}$ NMR $\left(\mathrm{CD}_{2} \mathrm{Cl}_{2}, 25{ }^{\circ} \mathrm{C}, 125 \mathrm{MHz}\right) \delta: 150.06,136.90,133.39,132.87,128.40,128.01$, $127.61,126.93,126.38,123.92,20.25$ ppm. ${ }^{31} \mathbf{P}$ NMR $\left(\mathrm{CD}_{2} \mathrm{Cl}_{2}, 25{ }^{\circ} \mathrm{C}, 283 \mathrm{MHz}\right): \delta+101.25\left(v_{1 / 2}=710.3\right.$ 
$\mathrm{Hz}),+83.15\left(v_{1 / 2}=1044.4 \mathrm{~Hz}\right) \mathrm{ppm}$. Elemental analysis found (calc.) for $\mathbf{Z n}_{\mathbf{3}}$ (phen) $)_{2}$ (Formula: $\mathrm{C}_{138} \mathrm{H}_{118} \mathrm{Co}_{6} \mathrm{~N}_{10} \mathrm{P}_{6} \mathrm{Se}_{8} \mathrm{Zn}_{3}$ ): Co 10.89 (10.77), Se 19.58 (19.24), P 5.50 (5.66).

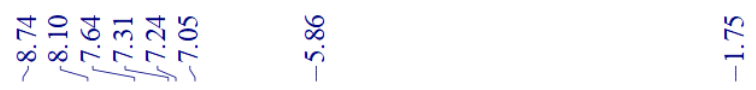

$\mathbf{Z n}_{\mathbf{3}}$ (phen $)_{2}$

${ }^{1} \mathrm{H}$ NMR Spectrum in $\mathrm{CD}_{2} \mathrm{Cl}_{2}(300 \mathrm{MHz})$

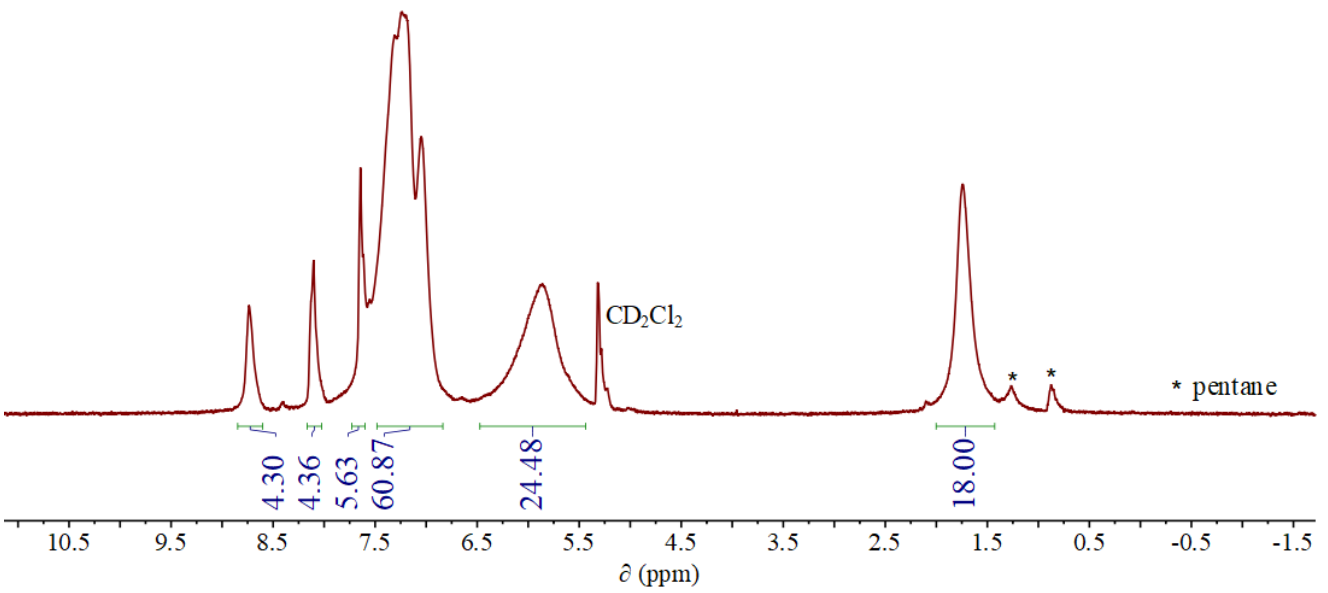

Figure S3. ${ }^{1} \mathrm{H}$ NMR $\left(\mathrm{CD}_{2} \mathrm{Cl}_{2}, 25{ }^{\circ} \mathrm{C}, 300 \mathrm{MHz}\right)$ spectrum of $\mathbf{Z n}_{3}$ (phen) $)_{2}$.

$\stackrel{2}{2} \stackrel{n}{a}$

$\mathbf{Z n}_{3}(\text { phen })_{2}$

${ }^{31} \mathrm{P}$ NMR Spectrum in $\mathrm{CD}_{2} \mathrm{Cl}_{2}(121 \mathrm{MHz})$
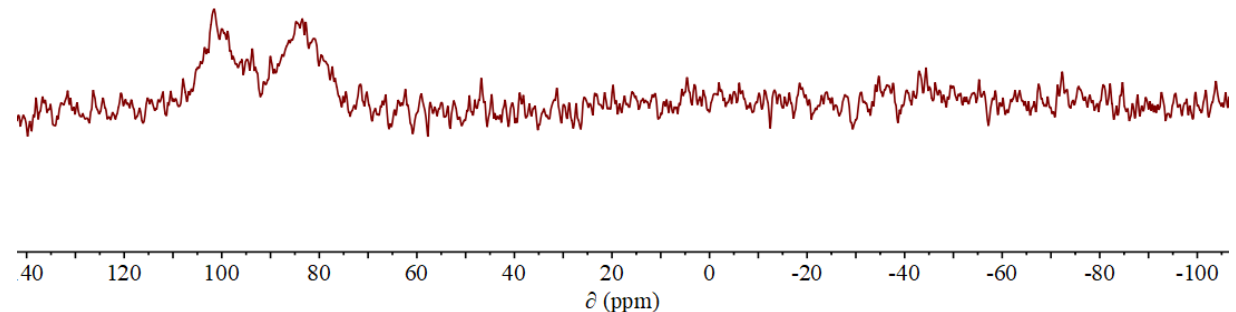

Figure S4. ${ }^{31} \mathrm{P} \mathrm{NMR}\left(\mathrm{CD}_{2} \mathrm{Cl}_{2}, 25{ }^{\circ} \mathrm{C}, 121 \mathrm{MHz}\right)$ spectrum of $\mathbf{Z n}_{3}(\text { phen })_{2}$ 
$\mathbf{Z n}_{3}$ (phen) $)_{2}$

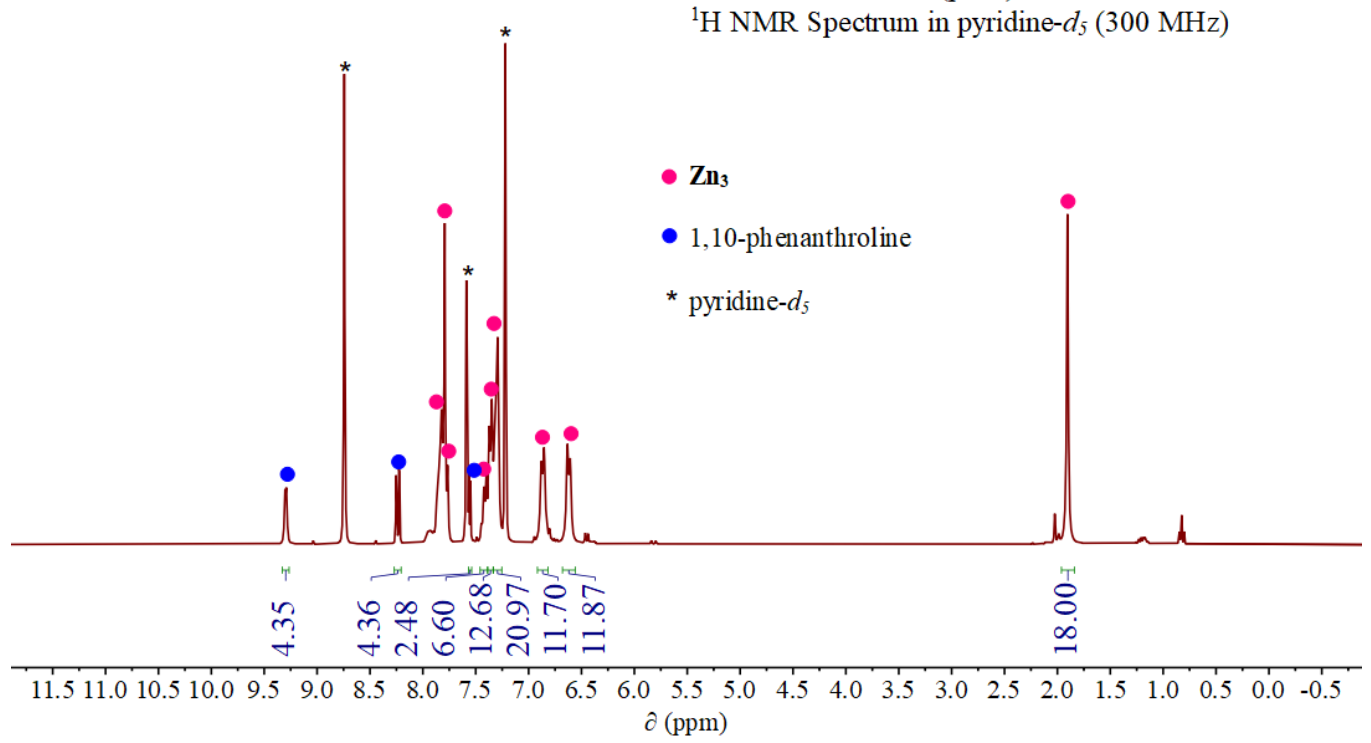

Figure S5. ${ }^{1} \mathrm{H}$ NMR (pyr- $d_{5}, 25{ }^{\circ} \mathrm{C}, 300 \mathrm{MHz}$ ) spectrum of $\mathbf{Z n}_{\mathbf{3}}$ (phen) $)_{2}$ after dissolution in pyridine- $d_{5}$ reveals formation of free 1,10-phenanthroline and $\mathbf{Z} \mathbf{n}_{3}(\mathrm{py})_{\mathrm{x}}$.

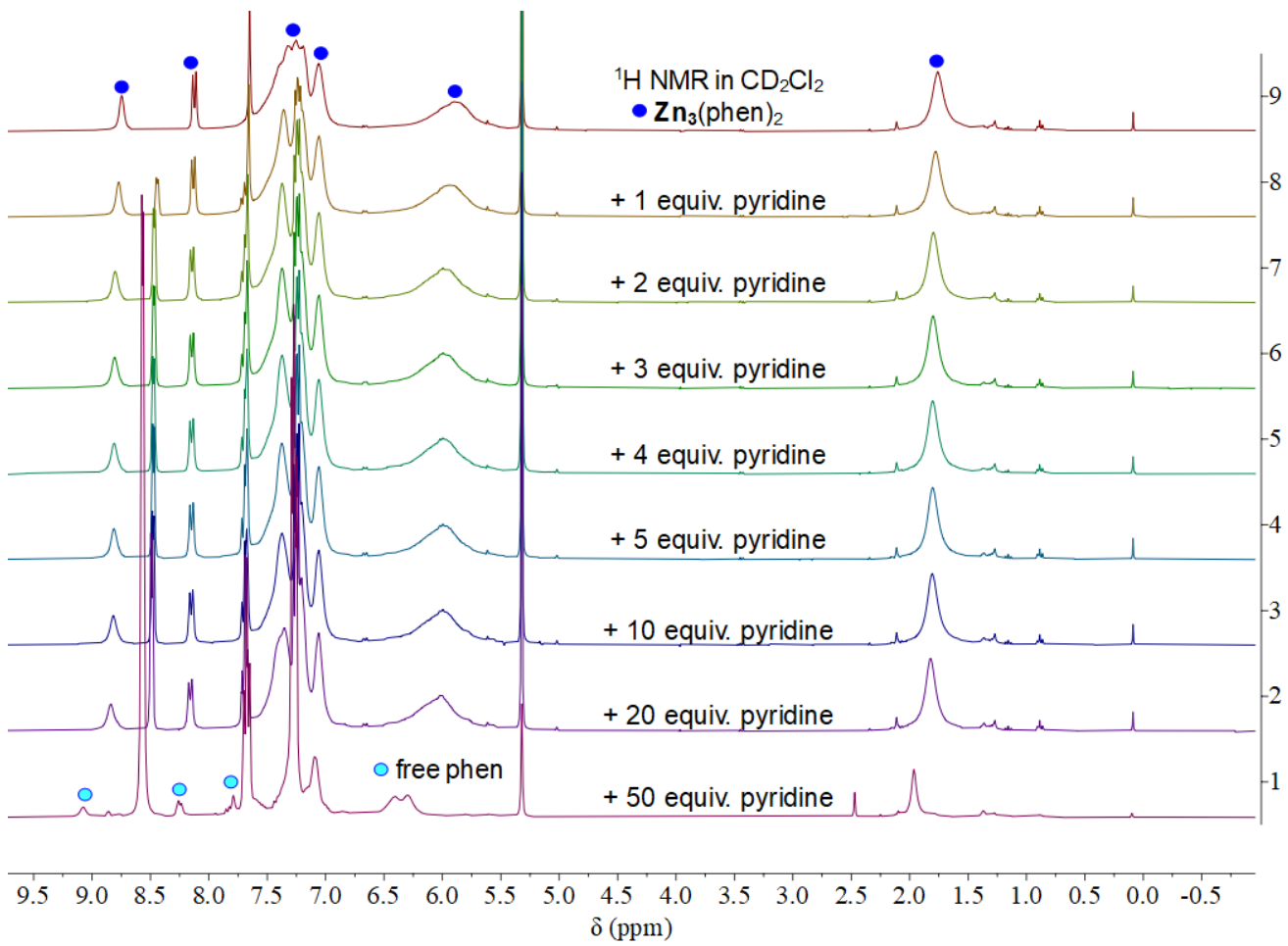

Figure S6. ${ }^{1} \mathrm{H}$ NMR $\left(\mathrm{CD}_{2} \mathrm{Cl}_{2}, 25^{\circ} \mathrm{C}, 300 \mathrm{MHz}\right)$ spectrum of a mixture of $\mathbf{Z} \mathbf{n}_{3}$ (phen)2 with increasing amounts of pyridine. 

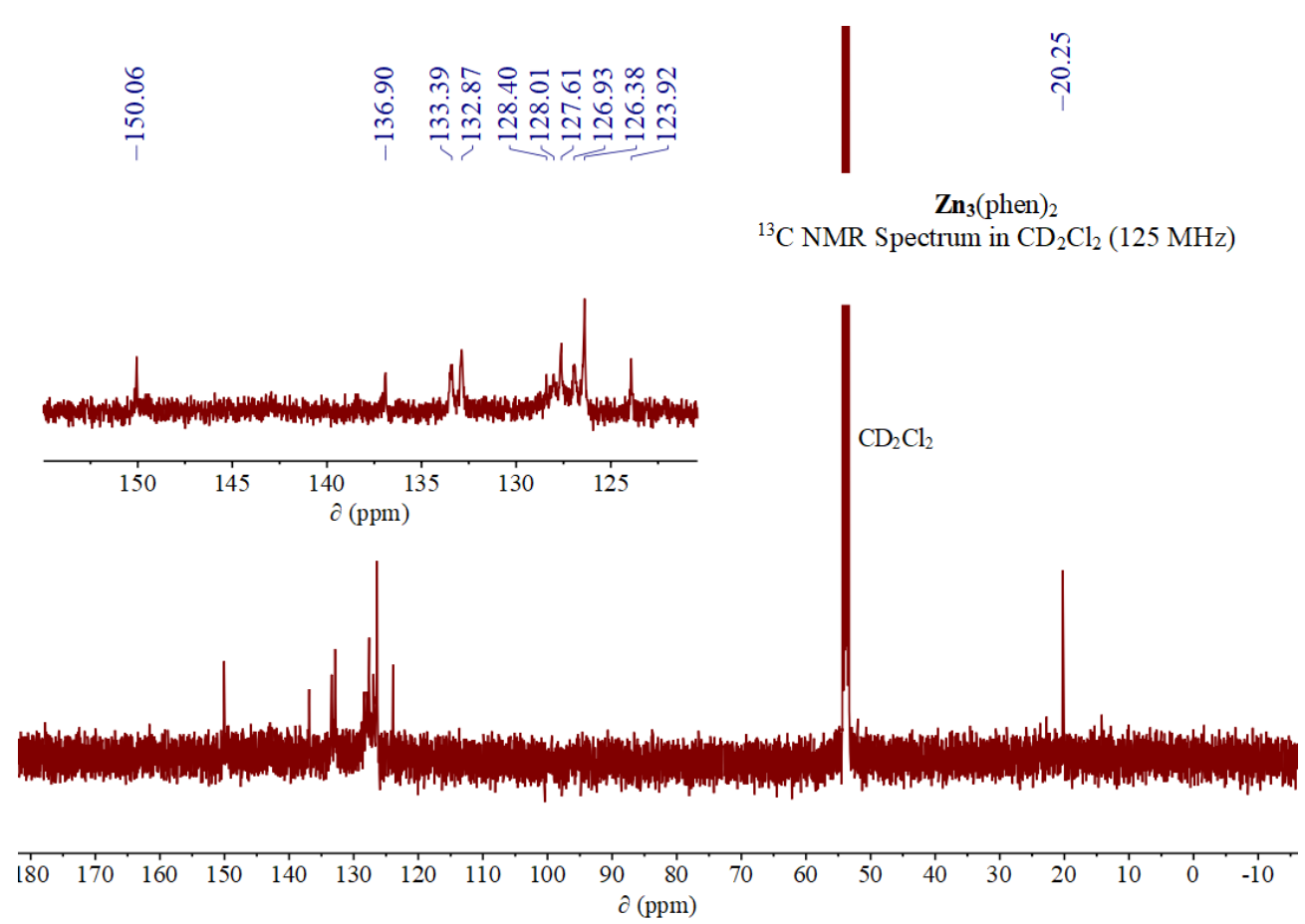

Figure S7. ${ }^{13} \mathrm{C}$ NMR $\left(\mathrm{CD}_{2} \mathrm{Cl}_{2}, 25{ }^{\circ} \mathrm{C}, 125 \mathrm{MHz}\right)$ spectrum of $\mathbf{Z n}_{3}(\text { phen })_{2}$.

\section{S2.4 Synthesis and isolation of $\left[\mathrm{Zn}_{3}(\text { phen })_{3} \mathrm{Co}_{6} \mathrm{Se}_{8} \mathrm{~L}_{6}\right]\left[\mathrm{PF}_{6}\right]\left(\left[\mathrm{Zn}_{3}(\text { phen })_{3}\right]\left[\mathrm{PF}_{6}\right]\right)$}

A $20 \mathrm{~mL}$ scintillation vial equipped with a magnetic stir bar was charged with $\mathbf{Z n}_{3}$ (py) $2(217 \mathrm{mg}, 0.071$ mmol, 1.0 equiv) and DCM $(8 \mathrm{~mL})$ and cooled in the glovebox freezer $\left(-35^{\circ} \mathrm{C}\right)$ for 15 minutes. A solution of ferrocenium hexafluorophosphate $(23 \mathrm{mg}, 0.071 \mathrm{mmol}, 1.0$ equiv) in DCM (2 mL) was added dropwise to the cold stirring solution of $\mathbf{Z n}_{3}(\mathrm{py})_{2}$. The reaction was allowed to stir for 15 minutes at room temperature and a solution of 1,10-phenanthroline (40 mg, $0.223 \mathrm{mmol}, 3.15$ equiv) in DCM (1 mL) was added dropwise. After two hours the reaction mixture was concentrated to half of its volume in vacuo, layered with $n$-pentane, and placed in the glovebox freezer $\left(-35^{\circ} \mathrm{C}\right)$ for 1 hour. The precipitate was collected on a medium porosity glass fritted funnel to yield a dark, black looking solid, identified as $\left[\mathrm{Zn}_{3}(\mathrm{phen})_{3}\right]\left[\mathrm{PF}_{6}\right]$ (202 mg, $0.057 \mathrm{mmol}, 80 \%$ yield). Single crystals suitable for X-ray diffraction studies were grown via the vapor diffusion of diethyl ether into a saturated solution of the product in acetonitrile at room temperature over the course of 2 days. ${ }^{1} \mathbf{H}$ NMR $\left(\mathrm{CD}_{2} \mathrm{Cl}_{2}, 300 \mathrm{MHz}\right) \delta: 8.76(\mathrm{~s}, 6 \mathrm{H}$, phen-ArH $), 8.10(\mathrm{~d}, 6 \mathrm{H}, J=8.1$ $\mathrm{Hz}$, phen-ArH), 7.70 (t, $\left.6 \mathrm{H}, J=7.1 \mathrm{~Hz}, \mathrm{PPh}_{2} \mathrm{p}-\mathrm{Ar} \boldsymbol{H}\right), 7.67$ (s, $6 \mathrm{H}$, phen-ArH), $7.61(\mathrm{t}, 6 \mathrm{H}, J=7.1 \mathrm{~Hz}$, $\left.\mathrm{PPh}_{2} \mathrm{p}-\mathrm{Ar} \boldsymbol{H}\right), 7.39$ (d, $\left.12 \mathrm{H}, \mathrm{PPh}_{2} \mathrm{o}-\mathrm{Ar} \boldsymbol{H}\right), 7.30$ (s, $\left.12 \mathrm{H}, \mathrm{PPh}_{2} \mathrm{o}-\mathrm{Ar} \boldsymbol{H}\right), 7.02$ (m, $6 \mathrm{H}$, phen-ArH $), 6.84(\mathrm{t}$, $\left.12 \mathrm{H}, J=6.2 \mathrm{~Hz}, \mathrm{PPh}_{2} \mathrm{~m}-\mathrm{Ar} \boldsymbol{H}\right), 6.46\left(\mathrm{t}, 12 \mathrm{H}, J=6.2 \mathrm{~Hz}, \mathrm{PPh}_{2} \mathrm{~m}-\mathrm{Ar} \boldsymbol{H}\right), 5.78(\mathrm{~d}, 12 \mathrm{H}, J=5.6 \mathrm{~Hz}$, tolyl $\operatorname{Ar} \boldsymbol{H}), 5.57(\mathrm{~d}, 12 \mathrm{H}, J=7.4 \mathrm{~Hz}$, tolyl $\mathrm{Ar} \boldsymbol{H}), 1.37$ (s, $18 \mathrm{H}, 4$-tolyl-CH$)$ ppm. ${ }^{13} \mathbf{C} \mathbf{~ N M R}\left(\mathrm{CD}_{2} \mathrm{Cl}_{2}, 125\right.$ MHz) $\delta 145.48$ (s, CH), 142.71 (s, C), 142.57 (s, C), 141.61 (s, C), 137.15 (s, CH), 134.36 (s, CH), 131.67 (s, CH), $128.72(\mathrm{~s}, \mathrm{C}), 128.32(\mathrm{~s}, \mathrm{C}), 128.22(\mathrm{~s}, \mathrm{CH}), 127.45(\mathrm{~s}, \mathrm{CH}), 127.27(\mathrm{~s}, \mathrm{CH}), 126.92(\mathrm{~s}, \mathrm{CH}), 126.52$ (s, CH), 126.23 (s, CH), 125.42 (s, CH), 124.04 (s, CH), 20.63 (s, $\left.\mathrm{CH}_{3}\right)$ ppm. ${ }^{31} \mathbf{P}$ NMR $\left(\mathrm{CD}_{2} \mathrm{Cl}_{2}, 121 \mathrm{MHz}\right)$ : $\delta-143.92\left(\mathrm{~m}, J_{\mathrm{FP}}=715 \mathrm{~Hz}\right),-521.23\left(v_{1 / 2}=2283 \mathrm{~Hz}\right) \mathrm{ppm} .{ }^{19} \mathbf{F} \mathbf{N M R}\left(\mathrm{CD}_{2} \mathrm{Cl}_{2}, 471 \mathrm{MHz}\right) \delta-73.85\left(\mathrm{~d}, J_{\mathrm{PF}}\right.$ $=711 \mathrm{~Hz})$ ppm. UV-vis: Figure S10. Elemental analysis found (calc.) for $\left[\mathbf{Z n}_{3}(\text { phen })_{3}\right]\left[\mathrm{PF}_{6}\right]$ (Formula: $\mathrm{C}_{150} \mathrm{H}_{126} \mathrm{Co}_{6} \mathrm{~F}_{6} \mathrm{~N}_{12} \mathrm{P}_{7} \mathrm{Se}_{8} \mathrm{Zn}_{3}$ ): Co 9.82 (9.80), Se 17.79 (17.51), P 5.67 (6.01). 


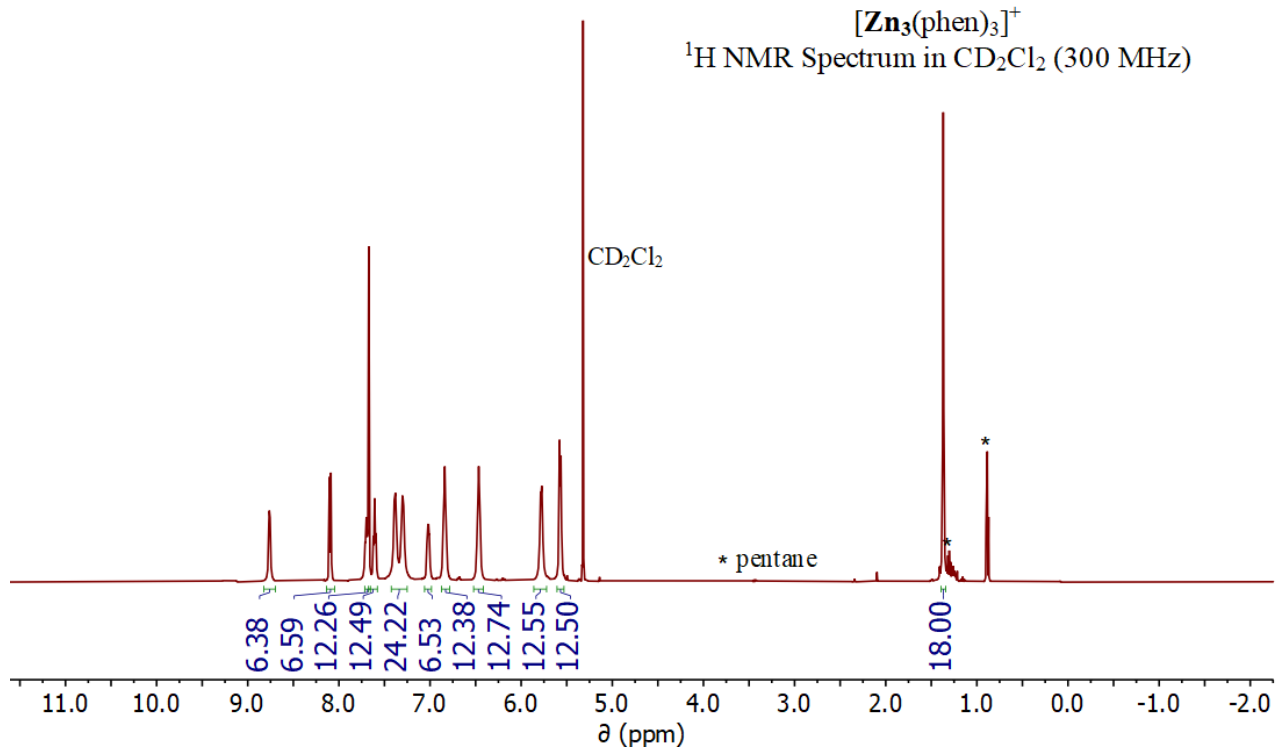

Figure S8. ${ }^{1} \mathrm{H}$ NMR $\left(\mathrm{CD}_{2} \mathrm{Cl}_{2}, 25{ }^{\circ} \mathrm{C}, 300 \mathrm{MHz}\right)$ spectrum of $\left.\left[\mathbf{Z n}_{3} \text { (phen }\right)_{3}\right]\left[\mathrm{PF}_{6}\right]$.

क 주ำ

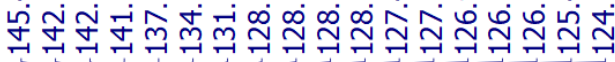

$\left.\left[\mathbf{Z n}_{3} \text { (phen }\right)_{3}\right]^{+}$

${ }^{13} \mathrm{C}$ NMR Spectrum in $\mathrm{CD}_{2} \mathrm{Cl}_{2}(125 \mathrm{MHz})$
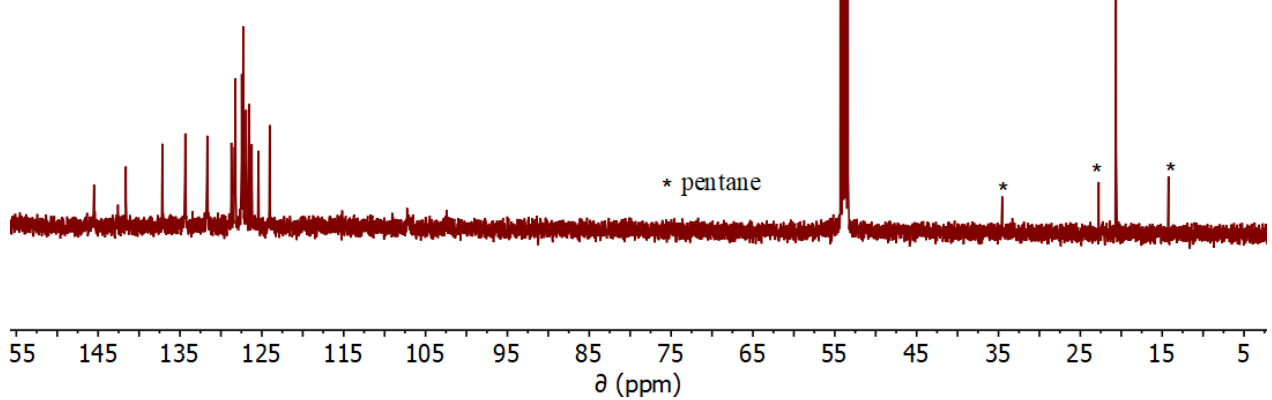

Figure S9. ${ }^{13} \mathrm{C}$ NMR $\left(\mathrm{CD}_{2} \mathrm{Cl}_{2}, 25{ }^{\circ} \mathrm{C}, 125 \mathrm{MHz}\right)$ spectrum of $\left[\mathbf{Z n}_{3}(\text { phen })_{3}\right]\left[\mathrm{PF}_{6}\right]$. 


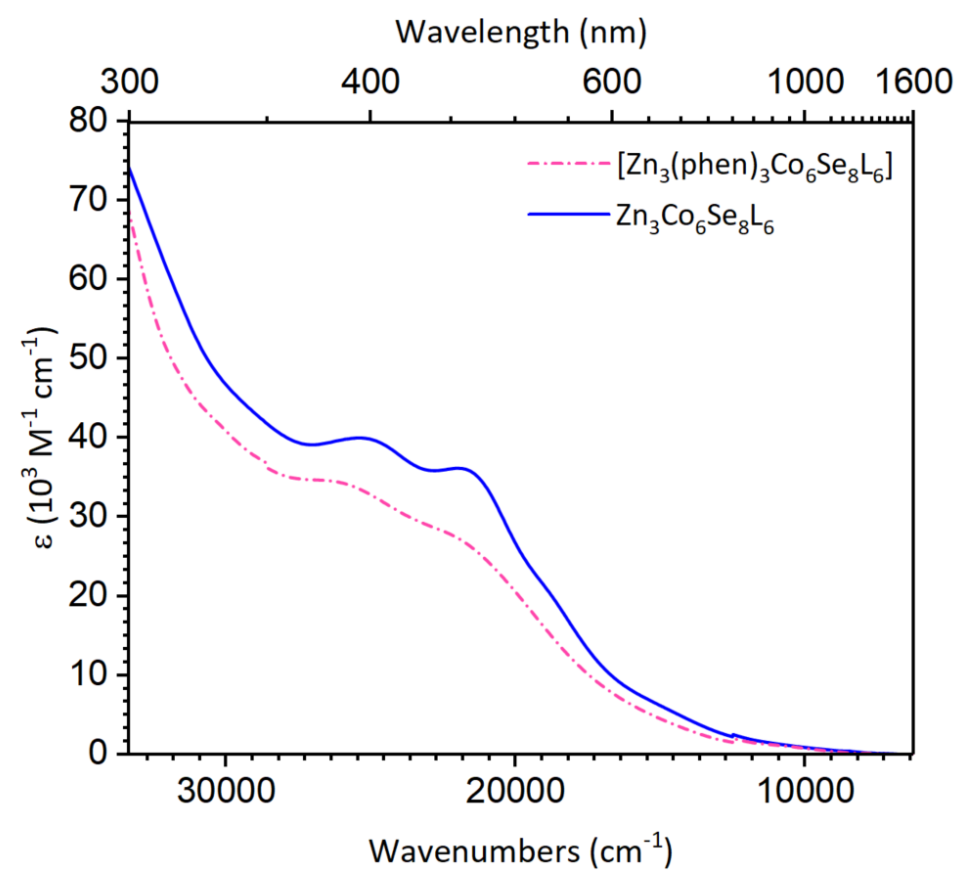

Figure S10. UV-Vis- $n$ IR absorption spectrum of $\mathbf{Z n}_{3}$ and $\left[\mathbf{Z n}_{3}(\mathrm{phen})_{3}\right]\left[\mathrm{PF}_{6}\right]$ in THF.

\section{S2.5 Synthesis and isolation of $\mathrm{Zn}_{3}$ (bipy) $\mathrm{Co}_{6} \mathrm{Se}_{8} \mathrm{~L}_{6}$ (1-bipy)}

$\mathbf{Z n}_{3}$ (py) 2 (50 mg, $0.016 \mathrm{mmol}, 1.0$ equiv) was dissolved in toluene $(5 \mathrm{~mL}$ ) with gentle heating and stirring over the course of 30 minutes. The solution was filtered through a plug of Celite into a $20 \mathrm{~mL}$ scintillation vial charged with 4,4'-bipyridine ( $4 \mathrm{mg}, 0.022 \mathrm{mmol}, 1.8$ equiv). The Celite plug was washed with additional toluene $(2 \mathrm{~mL})$. The reaction was allowed to sit undisturbed at $60{ }^{\circ} \mathrm{C}$. Dark prismatic crystals suitable for single crystal X-ray diffraction formed on the sides of the vial. After 2 days, the mother liquor was decanted, and the crystals were soaked in toluene $(3 \times 5 \mathrm{~mL} ; 15$ minutes each cycle), decanting the supernatant after each treatment. The volatiles were removed in vacuo to yield 1-bipy $(25 \mathrm{mg}, 0.0082 \mathrm{mmol}$, $51 \%$ yield). The material is insoluble in toluene and DCM but it dissolves in pyridine- $d_{5}$, reforming free monomer $\mathbf{Z n}_{3}(\mathrm{py})_{2}$ and 4,4'-bipyridine. Elemental analysis found (calc.) for 1-bipy (Formula: $\mathrm{C}_{124} \mathrm{H}_{110} \mathrm{Co}_{6} \mathrm{~N}_{8} \mathrm{P}_{6} \mathrm{Se}_{8} \mathrm{Zn}_{3}$ ): Co 11.25 (11.47), Se 20.76 (20.50), P 6.32 (6.03).

\section{S2.6 Formation and single crystal growth of $\mathrm{Zn}_{3}(\mathrm{tpphz}) \mathrm{Co}_{6} \mathrm{Se}_{8} \mathrm{~L}_{6}$ (1-tpphz)}

Tetrapyrido[3,2-a:2',3'-c:3",2"-h:2"', $\left.3^{\prime \prime \prime}-\mathrm{j}\right]$ phenazine (4 mg, $0.011 \mathrm{mmol}, 1.0$ equiv) was suspended in DCM $(8 \mathrm{~mL})$ and added to a solution of $\mathbf{Z n}_{3}$ (py $)_{2}(33 \mathrm{mg}, 0.011 \mathrm{mmol}, 1.0$ equiv) in DCM $(2 \mathrm{~mL})$. The reaction was allowed to stand at room temperature in the glovebox without stirring. After one week, a crystalline solid was collected on a fine porosity sintered glass filter. The material was washed with toluene $(\sim 15 \mathrm{~mL})$ and then DCM $(\sim 30 \mathrm{~mL})$ until the filtrate ran clear. The solids were brought to constant mass in vacuo to yield 1-tpphz as a dark crimson red solid (24 $\mathrm{mg}, 0.007 \mathrm{mmol}, 65 \%$ yield). The material is insoluble in toluene and DCM but can be digested in pyridine- $d_{5}$ reforming free monomer $\mathbf{Z n}_{3}(\mathrm{py})_{2}$. The insolubility of tpphz in pyridine- $d_{5}$ precludes its observation by NMR analysis after the digestion with pyridine. ${ }^{1} \mathbf{H}$ NMR (pyridine- $\left.d_{5}, 300 \mathrm{MHz}\right) \delta: 7.81(\mathrm{~m}, 24 \mathrm{H}), 7.40(\mathrm{~m}, 6 \mathrm{H}), 7.34(\mathrm{~m}, 12 \mathrm{H}), 7.28(\mathrm{~m}, 12 \mathrm{H}), 6.86(\mathrm{~d}, 12 \mathrm{H}, J$ $=7.9 \mathrm{~Hz}), 6.62(\mathrm{~d}, 12 \mathrm{H}, J=8.0 \mathrm{~Hz}), 1.90(\mathrm{~s}, 18 \mathrm{H}) \mathrm{ppm}$. Elemental analysis found (calc.) for 1-tpphz (Formula: $\mathrm{C}_{138} \mathrm{H}_{114} \mathrm{Co}_{6} \mathrm{~N}_{12} \mathrm{P}_{6} \mathrm{Se}_{8} \mathrm{Zn}_{3}$ ): Co 9.67 (10.69), Se 18.84 (19.10), P 6.01 (5.62). Incomplete digestion of 1-tpphz in concentrated nitric acid at $80{ }^{\circ} \mathrm{C}$ for 18 hours precluded accurate ICP-MS analysis. 
1-tpphz digested in in pyridine- $d_{5}$

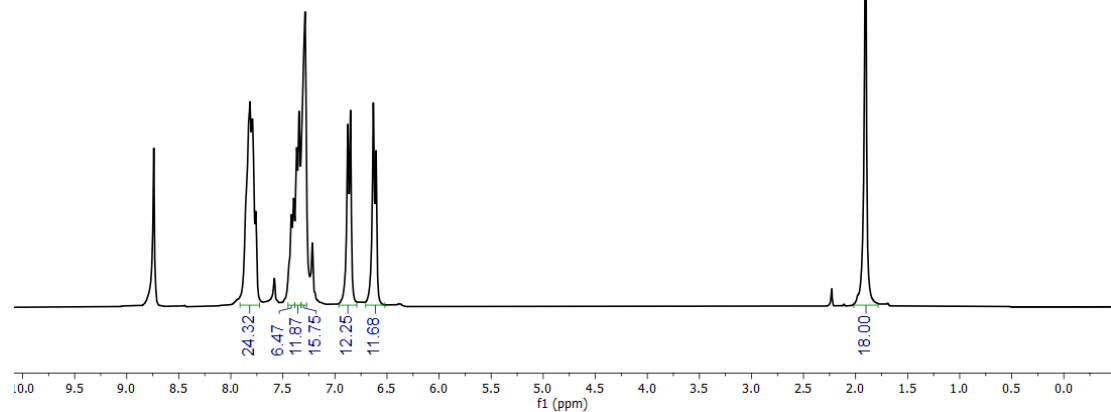

Figure S11. ${ }^{1} \mathrm{H}$ NMR (pyridine- $d_{5}, 25^{\circ} \mathrm{C}, 300 \mathrm{MHz}$ ) spectrum of 1-tpphz digested in pyridine- $d_{5}$. Due to the insolubility of tpphz in pyridine, the linker is not observed.

\section{S2.7 Synthesis and Isolation of $\left[\mathrm{Zn}_{3}(\mathrm{bpy})_{1.5} \mathrm{Co}_{6} \mathrm{Se}_{8} \mathrm{~L}_{6}\right]\left[\mathrm{PF}_{6}\right]$ (2-bipy)}

$\mathbf{Z n}_{3}$ (py) 2 (100 mg, $0.032 \mathrm{mmol}, 1.0$ equiv) and FcPF 6 (11 mg, $0.032 \mathrm{mmol}, 1.0$ equiv) were dissolved separately in DCM ( $7 \mathrm{~mL}$ and $3 \mathrm{~mL}$, respectively). The $\mathrm{FcPF}_{6}$ solution was added dropwise to the stirring solution of $\mathbf{Z n}_{3}(\mathrm{py})_{2}$ and the reaction was allowed to stir at room temperature for 10 minutes. The reaction mixture was filtered through a plug of Celite into a $20 \mathrm{~mL}$ scintillation vial charged with 4,4'-bipyridine (11 mg, $0.068 \mathrm{mmol}, 2.1$ equiv). The Celite plug was washed with additional DCM (2 mL). The reaction was allowed to sit undisturbed at room temperature. Dark prismatic crystals suitable for single crystal Xray diffraction formed on the sides of the vial. After 2 days, the mother liquor was decanted, and the crystals were soaked in DCM ( $3 \times 5 \mathrm{~mL} ; 15$ minutes each cycle), decanting the supernatant after each treatment. The volatiles were removed in vacuo to yield 2-bipy ( $45 \mathrm{mg}, 0.014 \mathrm{mmol}, 44 \%$ yield). The material is insoluble in toluene and DCM, however it dissolves in pyridine- $d_{5}$ forming free oxidized monomer, $\left[\mathbf{Z n}_{3}(\text { py })_{3}\right]\left[\mathrm{PF}_{6}\right]$ and 4,4'-bipyridine. Elemental analysis found (calc.) for 2-bpy (Formula: $\mathrm{C}_{129} \mathrm{H}_{114} \mathrm{Co}_{6} \mathrm{~F}_{6} \mathrm{~N}_{9} \mathrm{P}_{7} \mathrm{Se}_{8} \mathrm{Zn}_{3}$ ): Co 10.50 (10.46), Se 18.89 (18.69), P 6.39 (6.42).

Characterization of $\left[\mathbf{Z n}_{3}(\mathrm{py})_{3}\right]\left[\mathrm{PF}_{6}\right]$

${ }^{1}$ H NMR (pyridine- $\left.d_{5}, 500 \mathrm{MHz}\right) \delta: 8.86(\mathrm{~m}, 6 \mathrm{H}), 8.22(\mathrm{~m}, 12 \mathrm{H}), 8.10(\mathrm{~m}, 6 \mathrm{H}), 7.91(\mathrm{~m}, 6 \mathrm{H}), 7.76(\mathrm{~s}$, $12 \mathrm{H}), 7.61(\mathrm{~m}, 6 \mathrm{H}), 6.99(\mathrm{~s}, 12 \mathrm{H}), 6.85(\mathrm{~s}, 12 \mathrm{H}), 6.79(\mathrm{~d}, 12 \mathrm{H}, J=8.0 \mathrm{~Hz}), 6.49(\mathrm{~d}, 12 \mathrm{H}, J=7.0 \mathrm{~Hz})$, $1.66(\mathrm{~s}, 18 \mathrm{H}) \mathrm{ppm} .{ }^{13} \mathrm{C}$ NMR (pyridine- $\left.d_{5}, 125 \mathrm{MHz}\right) \delta 151.64(\mathrm{~s}), 145.76(\mathrm{~s}), 134.12$ (s), $131.25(\mathrm{~s})$, 130.20 (s), 128.93 (s), 128.73 (s), 127.72 (s), 126.05 (s), 124.77 (s), 122.15 (s), 21.32 (s) ppm. ${ }^{31} \mathbf{P}$ NMR (pyridine- $d_{5}, 121 \mathrm{MHz}$ ): $\delta-142.30$ (sept, $J_{\mathrm{FP}}=712 \mathrm{~Hz}$ ) ppm. The aminophosphine ${ }^{31} \mathrm{P}$ feature was not observed. ${ }^{19} \mathbf{F}$ NMR (pyridine- $\left.d_{5}, 470 \mathrm{MHz}\right) \delta-71.26\left(\mathrm{~d}, J_{\mathrm{PF}}=710 \mathrm{~Hz}\right) \mathrm{ppm}$.

\section{S2.8 Reaction of $\mathrm{Zn}_{3}(\mathrm{py})_{2}$ with [Ru(bipy') $)_{2}$ (phendione)][PF$]_{2}$ : synthesis of 3}

A solution of $[\mathrm{Ru} \text { (bipy') })_{2}$ (phendione) $]\left[\mathrm{PF}_{6}\right]_{2}(11 \mathrm{mg}, 0.012 \mathrm{mmol}, 1.0$ equiv) in acetonitrile $(1 \mathrm{~mL})$ was added dropwise to a stirring solution of $\mathbf{Z n}_{3}(\mathrm{py})_{2}$ (34 $\mathrm{mg}, 0.012,1.0$ equiv) in toluene $(2 \mathrm{~mL})$. The reaction was stirred at room temperature for 10 minutes and then concentrated under reduced pressure. The residue was triturated with diethyl ether $(2 \times 4 \mathrm{~mL})$ and then washed with $n$-pentane $(\sim 10 \mathrm{~mL})$ and diethyl ether $(\sim 10 \mathrm{~mL})$. The product was completely solubilized in acetonitrile and passed through a plug Celite. Notably, the starting $\mathbf{Z n}_{3}(\mathrm{py})_{2}$ is completely insoluble in acetonitrile. The volatiles were removed in vacuo to yield 
a dark, black looking, solid (45 mg, $0.011 \mathrm{mmol}, 92 \%$ yield) ${ }^{1} \mathbf{H}$ NMR $\left(\mathrm{CD}_{3} \mathrm{CN}, 500 \mathrm{MHz}\right)$ 8.47, 7.99, 7.83, 7.77, 7.66, 7.56, 7.52, 7.40, 7.33, 6.94, 6.88, 6.87, 6.81, 6.72, 6.59, 6.34, 6.27, 6.21, 1.74 (s, $12 \mathrm{H}), 1.68$ (s, $6 \mathrm{H}) \mathrm{ppm} .{ }^{31} \mathbf{P}$ NMR $\left(\mathrm{CD}_{3} \mathrm{CN}, 202 \mathrm{~Hz}\right)-144\left(\mathrm{sept}, J_{\mathrm{FP}}=707 \mathrm{~Hz}\right),-415\left(v_{1 / 2}=1445 \mathrm{~Hz}\right) \mathrm{ppm}$. ATR-FTIR (film): $\quad v_{\mathrm{SQ}}=1464 \mathrm{~cm}^{-1}$. Elemental analysis found (calc.) for $\mathbf{3}$ (Formula: $\mathrm{C}_{156} \mathrm{H}_{134} \mathrm{Co}_{6} \mathrm{~F}_{12} \mathrm{~N}_{14} \mathrm{O}_{2} \mathrm{P}_{8} \mathrm{RuSe}_{8} \mathrm{Zn}_{3}$ ): Co 8.56 (8.85), Se 16.16 (15.81), P 6.56 (6.20).
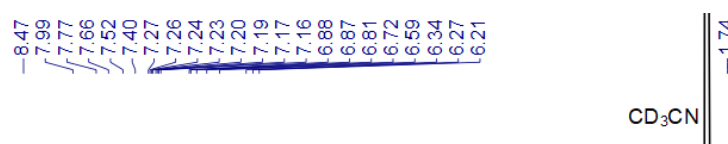

${ }^{1} \mathrm{H} N M R$ in $\mathrm{CD}_{3} \mathrm{CN}(500 \mathrm{MHz})$

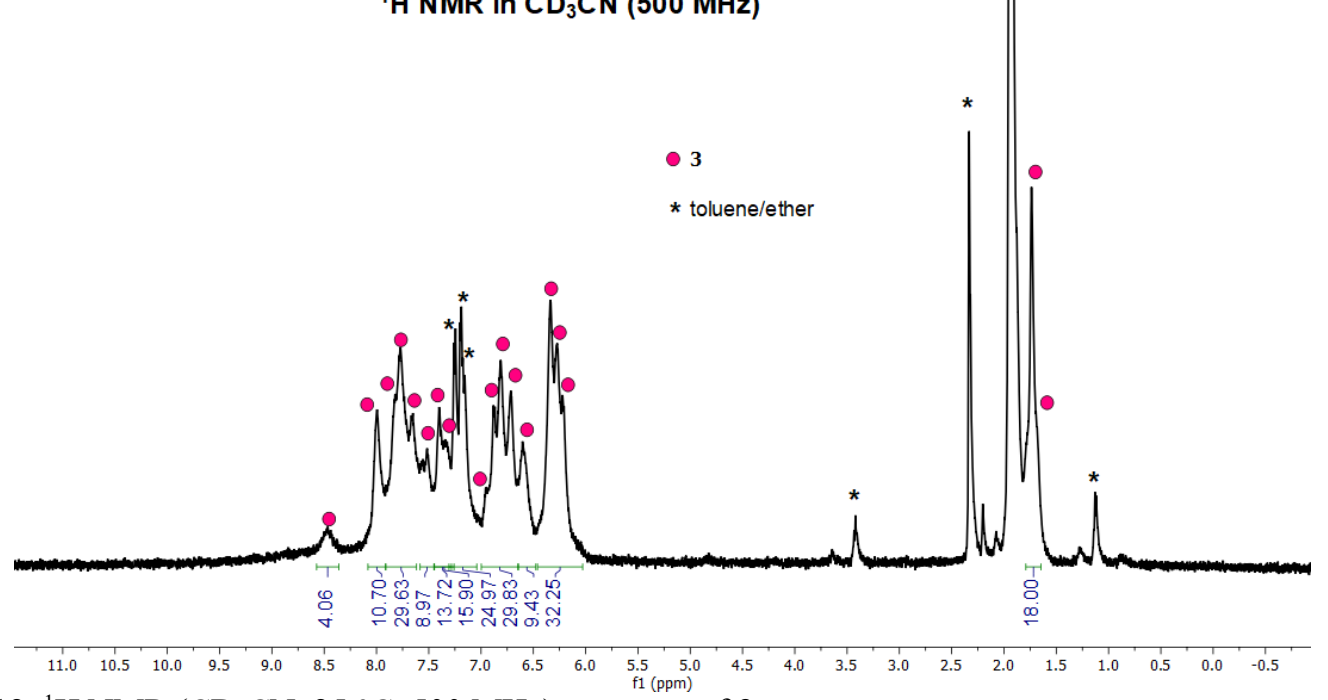

Figure $\mathrm{S} 12 .{ }^{1} \mathrm{H} \mathrm{NMR}\left(\mathrm{CD}_{3} \mathrm{CN}, 25^{\circ} \mathrm{C}, 500 \mathrm{MHz}\right)$ spectrum of 3 .

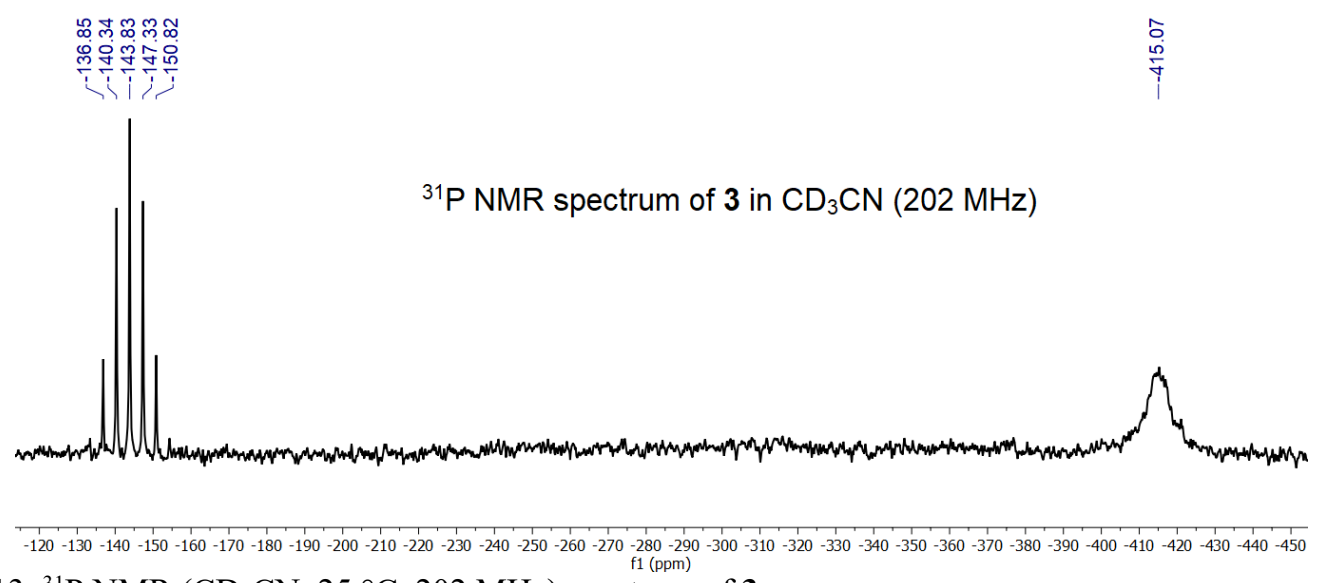

Figure S13. ${ }^{31} \mathrm{P}$ NMR $\left(\mathrm{CD}_{3} \mathrm{CN}, 25^{\circ} \mathrm{C}, 202 \mathrm{MHz}\right)$ spectrum of 3. 

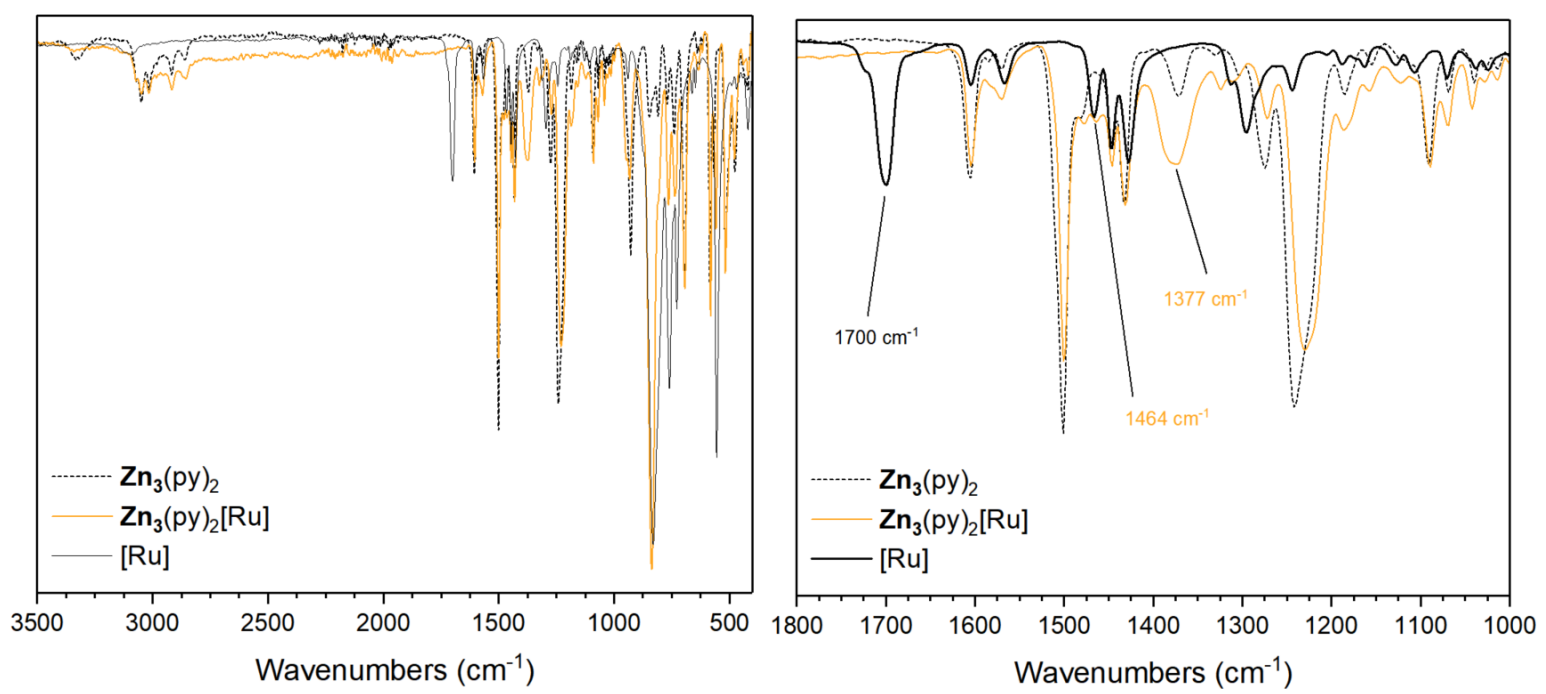

Figure S14. IR spectra of $\mathbf{Z n}_{3}(\text { py })_{2}$, [Ru(bipy') $)_{2}$ (phendione) $]\left[\mathrm{PF}_{6}\right]_{2}$, and $\mathbf{3}$.

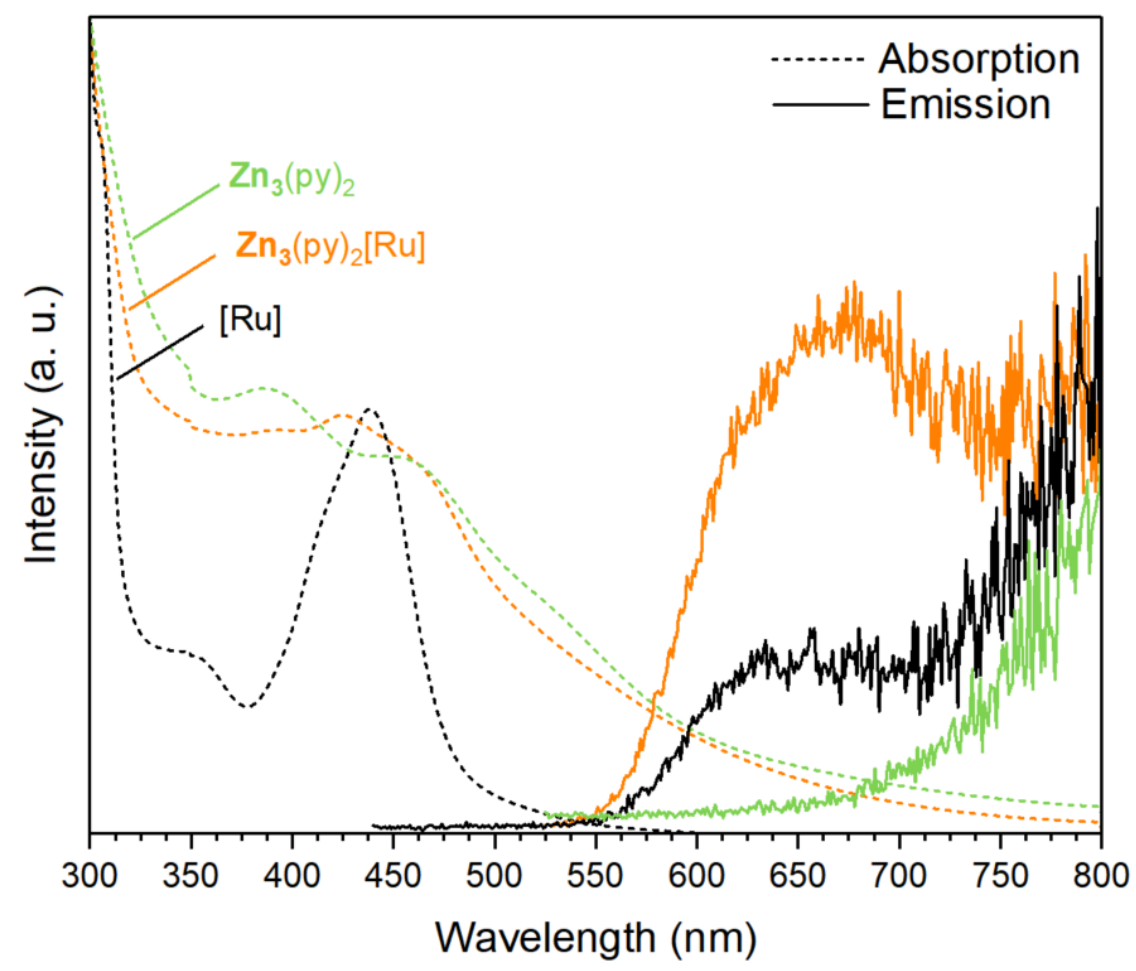

Figure S15. Absorption and emission spectra of $\mathbf{Z n}_{3}(\mathrm{py})_{2}, \mathbf{3}$ and $\left[\mathrm{Ru}(\text { bipy') })_{2}(\right.$ phendione $\left.)\right]\left[\mathrm{PF}_{6}\right]_{2}$ in $\mathrm{MeCN}$. 


\section{S3 Electrochemistry}

Table S1. Half-wave potentials $\left(\mathrm{E}_{1 / 2}\right)$ and peak-to-peak separation potentials $\left(\Delta \mathrm{E}_{\mathrm{p}}\right)$ of $\mathrm{Co}_{6} \mathrm{Se}_{8} \mathrm{~L}_{6}{ }_{6}$ and $\mathbf{Z n}_{3}(p y)_{2}$

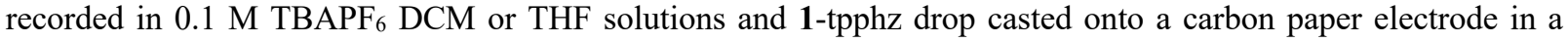
solution of $0.1 \mathrm{M} \mathrm{TBAPF}_{6}$ in $\mathrm{MeCN}$. All samples measured at a scan rate of $200 \mathrm{mV} / \mathrm{s}$. Values recorded in DCM and THF solutions are reported with and without parenthesis, respectively.

\begin{tabular}{cccc}
\hline \multirow{2}{*}{ redox couple $\left(\mathrm{n}_{\text {red }} / \mathrm{n}_{\mathrm{ox}}\right)$} & \multicolumn{3}{c}{$\mathrm{E}_{1 / 2}\left(\mathrm{~V} \mathrm{vs} \mathrm{Fc}^{0 /+}\right) ; \Delta \mathrm{E}_{\mathrm{p}}(\mathrm{mV})$} \\
\cline { 2 - 4 } & $\mathrm{Co}_{6} \mathrm{Se}_{8}{ }^{\mathrm{H}} \mathrm{L}_{6}$ & $\mathbf{Z n}_{3}(\mathrm{py})_{2}$ & 1-tpphz \\
\hline$+3 /+4$ & $1.01 ; 110$ & - & - \\
$+2 /+3$ & $0.57(0.41) ; 110(201)$ & $0.49 ; 131$ & - \\
$+1 /+2$ & $0.05(-0.08) ; 131(201)$ & $0.12(-0.05) ; 181(180)$ & $-0.02(\mathrm{irr})$ \\
$0 /+1$ & $-0.63(-0.69) ; 110(191)$ & $-0.37(-0.67) ; 121(190)$ & $-0.65 ; 122$ \\
$-1 / 0$ & $-1.98(-2.13) ; 151(313)$ & $-1.59(-1.77) ; 111(170)$ & $-1.14(\mathrm{irr})$
\end{tabular}

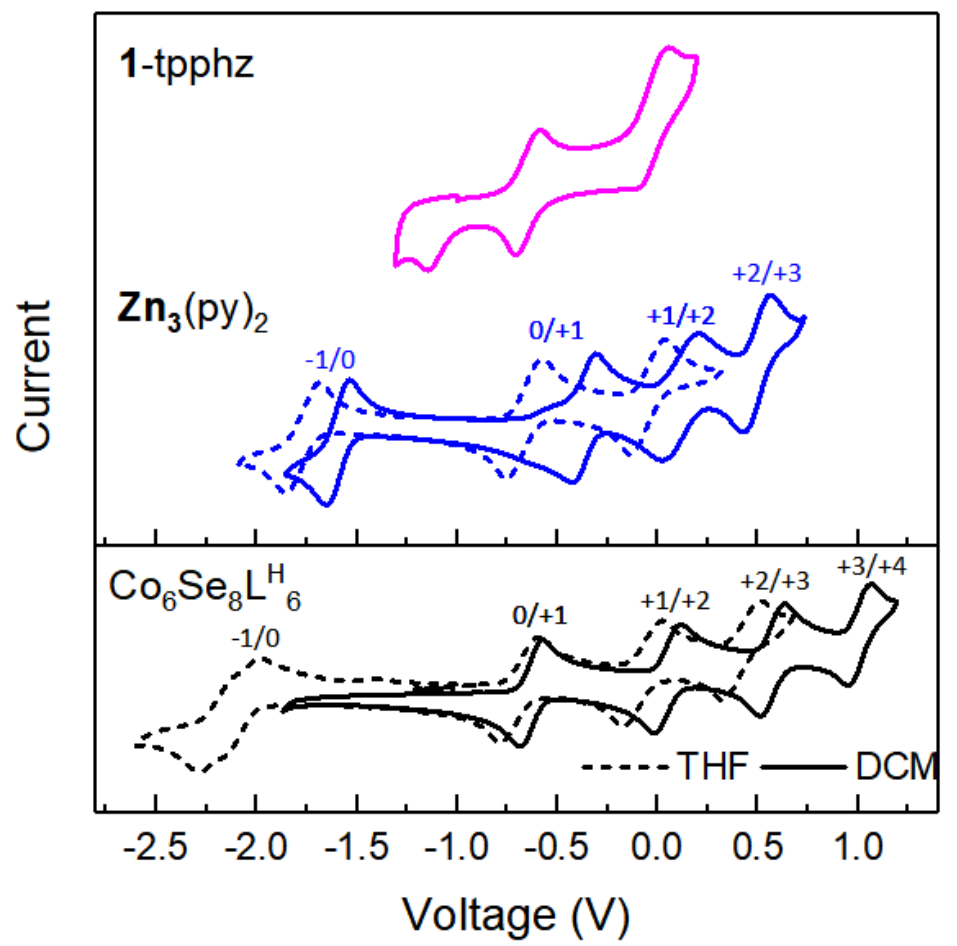

Figure S16. Cyclic voltammograms of $\mathrm{Co}_{6} \mathrm{Se}_{8} \mathrm{~L}_{6}{ }_{6}$ and $\mathbf{Z n}_{3}(\mathrm{py})_{2}$ recorded in DCM (solid) and THF (dashed) solutions with $\mathrm{TBAPF}_{6}(0.1 \mathrm{M})$ at $200 \mathrm{mV} / \mathrm{s}$. Due to the instability of the 1-tpphz in THF and the limited electrochemical window of DCM, the solid state cyclic voltammogram of 1-tpphz was recorded in a MeCN solution with $\mathrm{TBAPF}_{6}(0.1 \mathrm{M})$ at $200 \mathrm{mV} / \mathrm{s}$. 

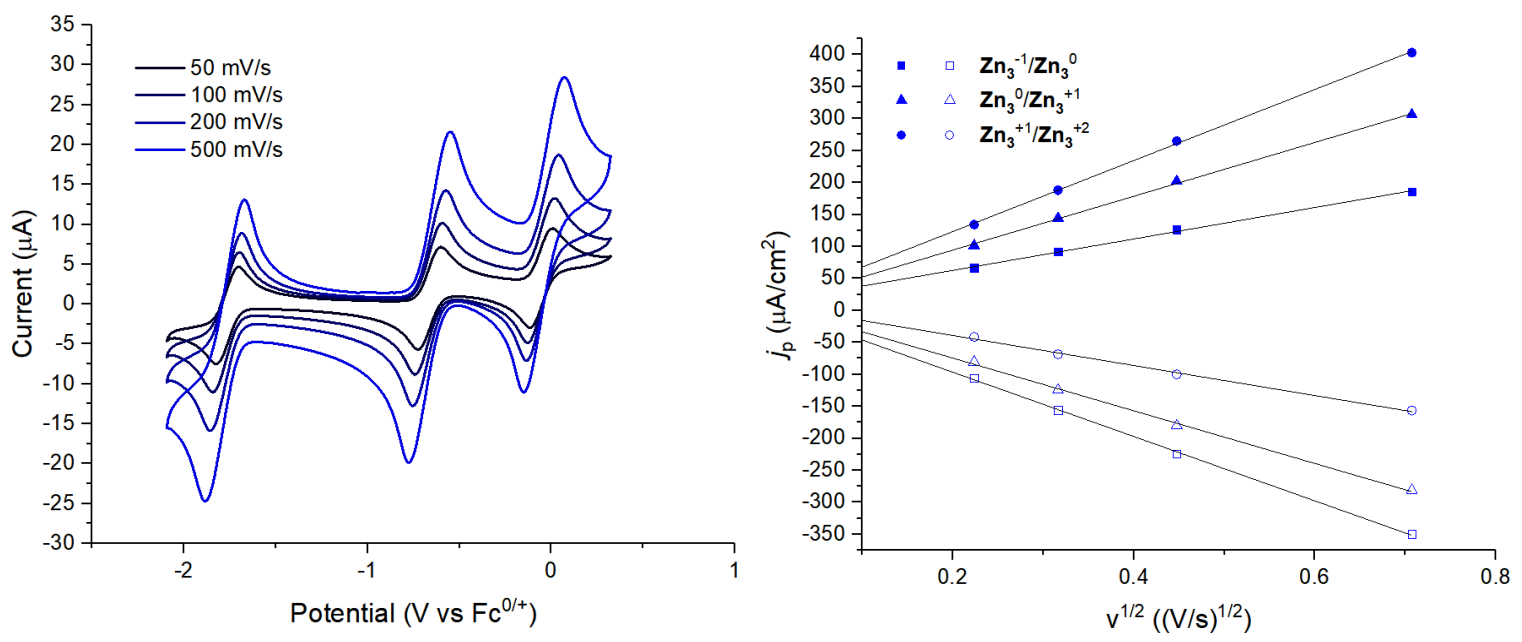

Figure S17. Cyclic voltammograms of $\mathbf{Z n}_{3}(\mathrm{py})_{2}$ recorded between 50 and $500 \mathrm{mV} \mathrm{s}^{-1}$ in THF ( $\left.0.1 \mathrm{M} \mathrm{TBAPF}_{6}\right)$ and referenced to ferrocene/ferrocenium (left) and plot of current density $\left(j_{\mathrm{p}}\right)$ versus the square root of scan rate $\left(\mathrm{v}^{1 / 2}\right)$ with linear fits used to model the data with the Randels-Sevcik equation (right).

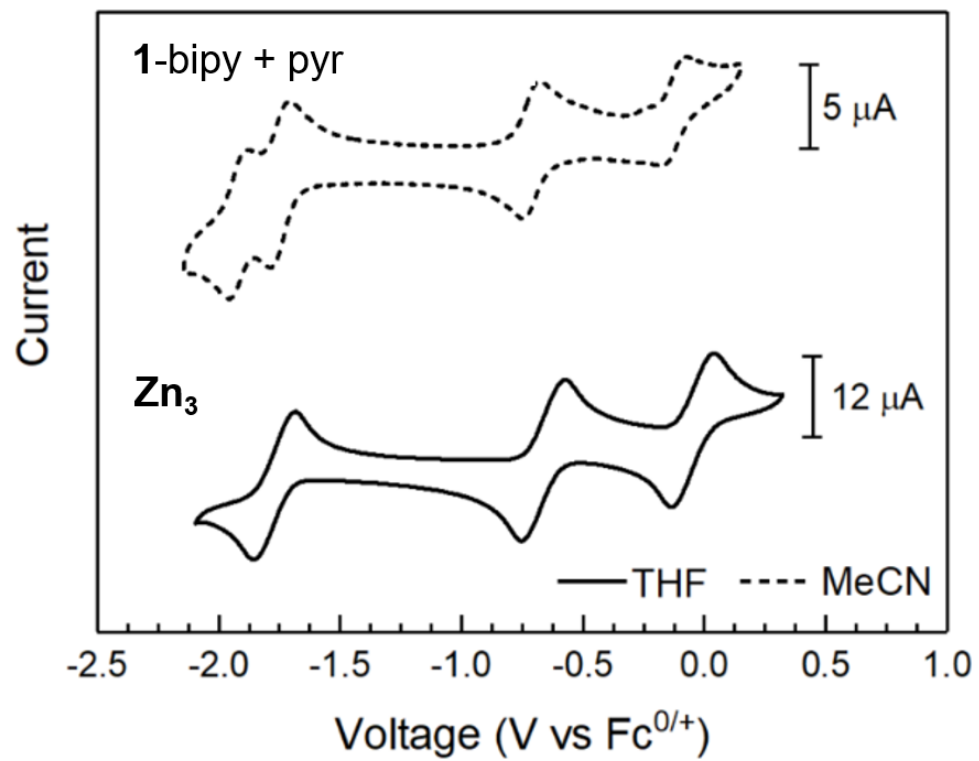

Figure S18. Cyclic voltammograms of $\mathbf{Z n}_{3}(\mathrm{py})_{2}$ in THF (0.1 M TBAPF $\left.{ }_{6}\right)$ and the 1-bipy nanowire digested in pyridine and recorded in $\mathrm{MeCN}\left(0.1 \mathrm{M} \mathrm{TBAPF}_{6}\right)$. 


\section{S4 X-ray Diffraction Studies}

Single crystals suitable for X-ray analysis were coated in deoxygenated paratone oil and mounted on a 20 $\mu \mathrm{m}$ CryoLoop $^{\mathrm{TM}}$ (Hampton Research, $18 \mathrm{~mm}$ mount, 0.2 to $0.3 \mathrm{~mm}$ loop diameter). Data was collected at $-173{ }^{\circ} \mathrm{C}$ on a Bruker APEX II single crystal X-ray diffractometer, with a Mo source. Data was integrated and scaled using SAINT, SADABS within the APEX2 software package by Bruker. ${ }^{4}$ Solution by direct methods (SHELXT ${ }^{5}$ or SIR97 ${ }^{6,7}$ ) produced a complete heavy atom phasing model consistent with the proposed structure. Structures were completed by difference Fourier synthesis with SHELXL ${ }^{8-10}$ Scattering factors are from Waasmair and Kirfel. ${ }^{11}$ Hydrogen atoms were placed in geometrically idealized positions and constrained to ride on their parent atoms with $\mathrm{C}-\mathrm{H}$ distances in the range $0.95-1.00 \AA$. Isotropic thermal parameters $\mathrm{U}_{\text {eq }}$ were fixed such that they were $1.2 \mathrm{U}_{\text {eq }}$ of their parent atom $\mathrm{Ueq}$ for $\mathrm{CHs}$ and $1.5 \mathrm{U}_{\text {eq }}$ of their parent atom $\mathrm{U}_{\mathrm{eq}}$ in case of methyl groups. All non-hydrogen atoms were refined anisotropically by fullmatrix least-squares.

\section{S4.1 $\quad \mathrm{Zn}_{3}(\mathrm{THF})_{2}$}

Thin, dark-red prismatic crystals suitable for Xray analysis were grown via vapor diffusion of diethyl ether into a saturated solution of $\mathbf{Z n}_{\mathbf{3}}(\mathrm{py})_{2}$ in THF at room temperature over the course of 5 days. The asymmetric unit contains a full cluster with two of the three zinc atoms bound by THF, and an unbound, disordered THF molecule that was modeled over two positions.

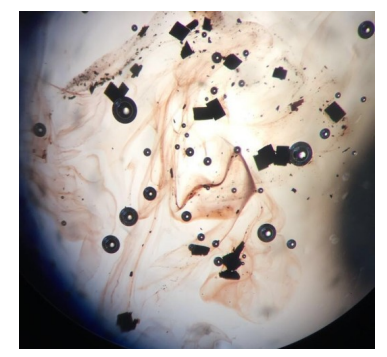

Figure S19. Microscope image of $\mathbf{Z n}_{3}(\mathrm{THF})_{2}$ Crystals.
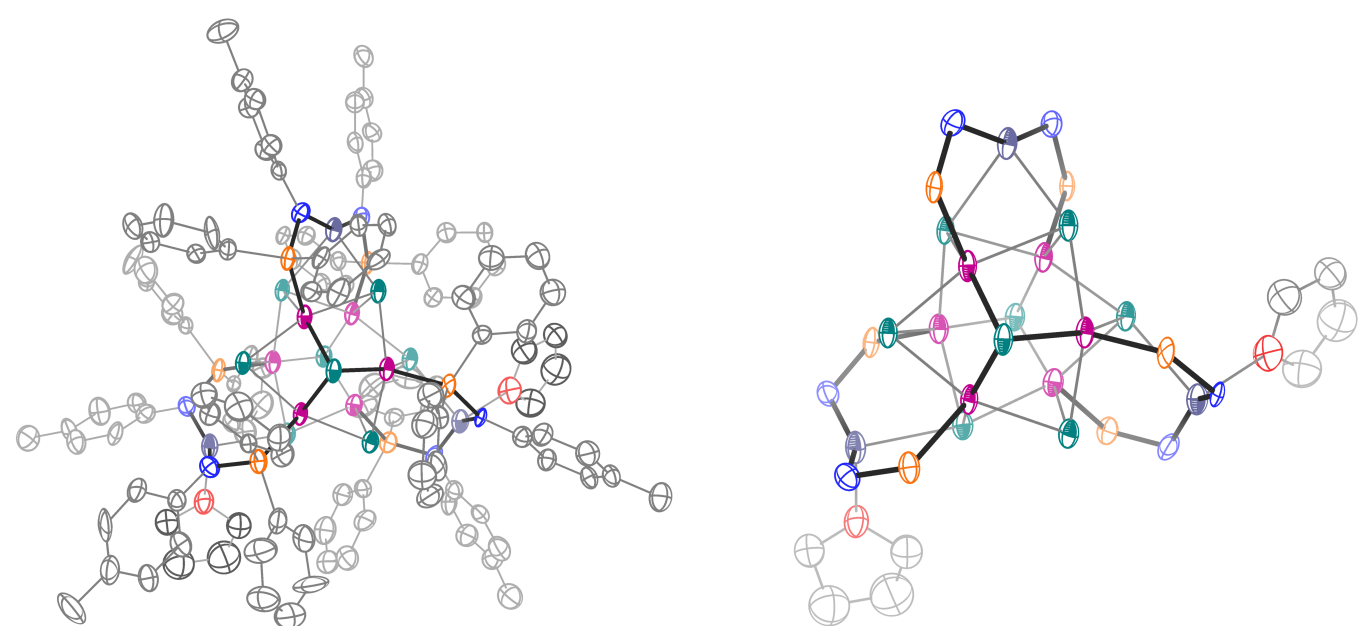

Figure S20. Molecular structure of $\mathbf{Z n}_{3}(\mathrm{THF})_{2}$ with thermal ellipsoids shown at a $50 \%$ probability level. 


\section{S4.2 $\quad \mathbf{Z n}_{\mathbf{3}}$ (phen) $)_{2}$}

Dark-red prismatic crystals suitable for X-ray diffraction studies were grown over the course of two days via vapor diffusion of diethyl ether into a saturated solution of $\mathbf{Z n}_{3}$ (phen) $)_{2}$ in THF at room temperature. The asymmetric unit contains two clusters of opposite helical chirality. The phenyl and tolyl groups of three aminophosphines are disordered over two positions.

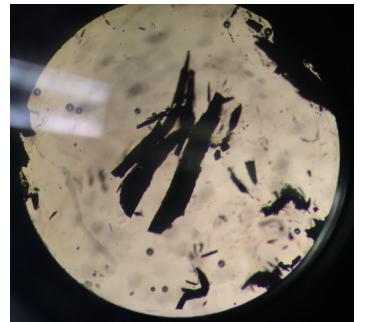

Figure S21 Microscope image of $\mathbf{Z n}_{3}(\mathrm{phen})_{2}$ crystals.
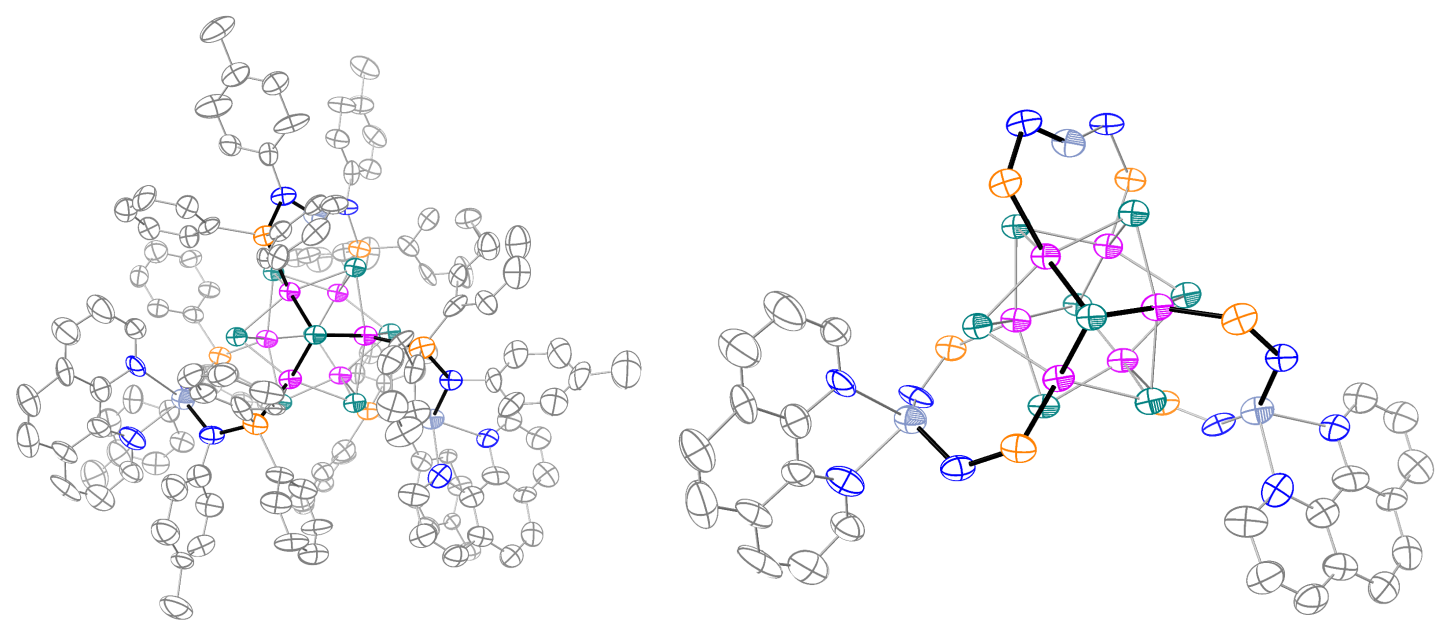

Figure S22. Molecular structure of $\mathbf{Z n}_{3}$ (phen) $)_{2}$ with thermal ellipsoids shown at a 50\% probability level.

\section{S4.3 $\left[\mathrm{Zn}_{3}(\text { phen })_{3}\right]\left[\mathrm{PF}_{6}\right]$}

Dark-red prismatic crystals were grown via vapor diffusion of diethyl ether into a saturation solution $\left.\left[\mathbf{Z n}_{3} \text { (phen) }\right)_{3}\right]\left[\mathrm{PF}_{6}\right]$ in acetonitrile at room temperature over the course of two days. The asymmetric unit contains one cluster with a disordered $\mathrm{PF}_{6}{ }^{-}$anion, and two acetonitrile molecules and one diethyl ether molecule. 

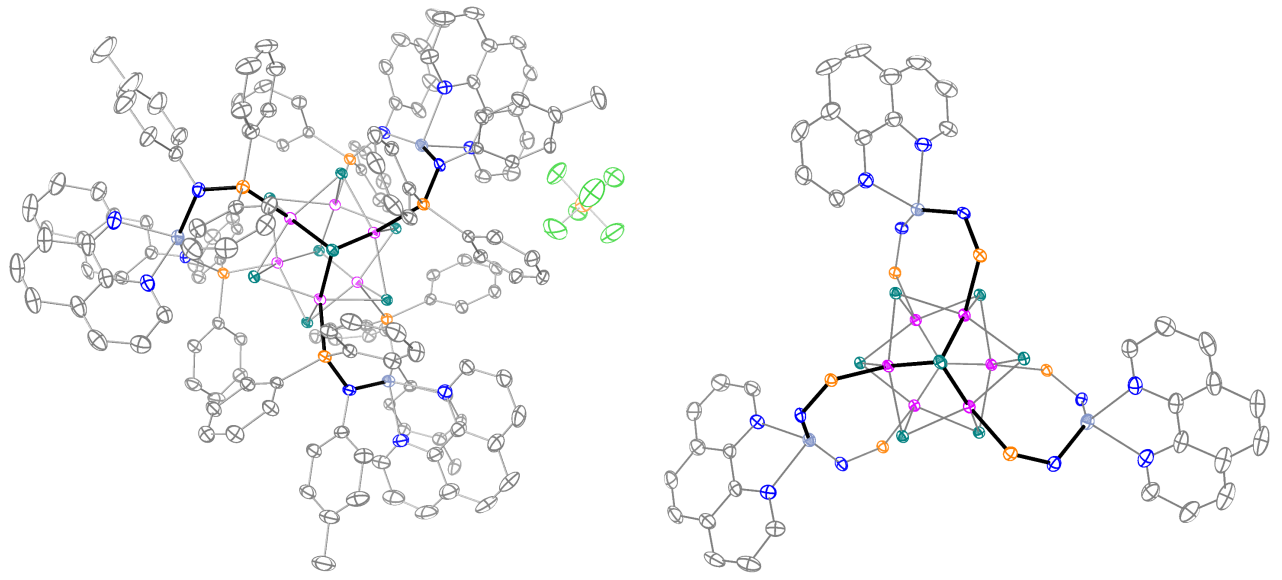

Figure S23. Molecular structure of $\left[\mathbf{Z n}_{3}(\mathrm{phen})_{3}\right]\left[\mathrm{PF}_{6}\right]$ with thermal ellipsoids shown at a $50 \%$ probability level.

\section{S4.4 1-bipy}

Dark red prismatic crystals were grown from the reaction mixture at $60{ }^{\circ} \mathrm{C}$ over the course of two days. The data was of slightly reduced quality due to possible growth defects, and with some solvent toluene disorder present, a few restraints were required (ISOR on all carbon, nitrogen and DELU on carbon, nitrogen and connecting phosphorous, AFIX 66 on toluene rings, flat and EADP on disordered toluene) and 450 bad reflections were omitted $(0.34 \%)$.
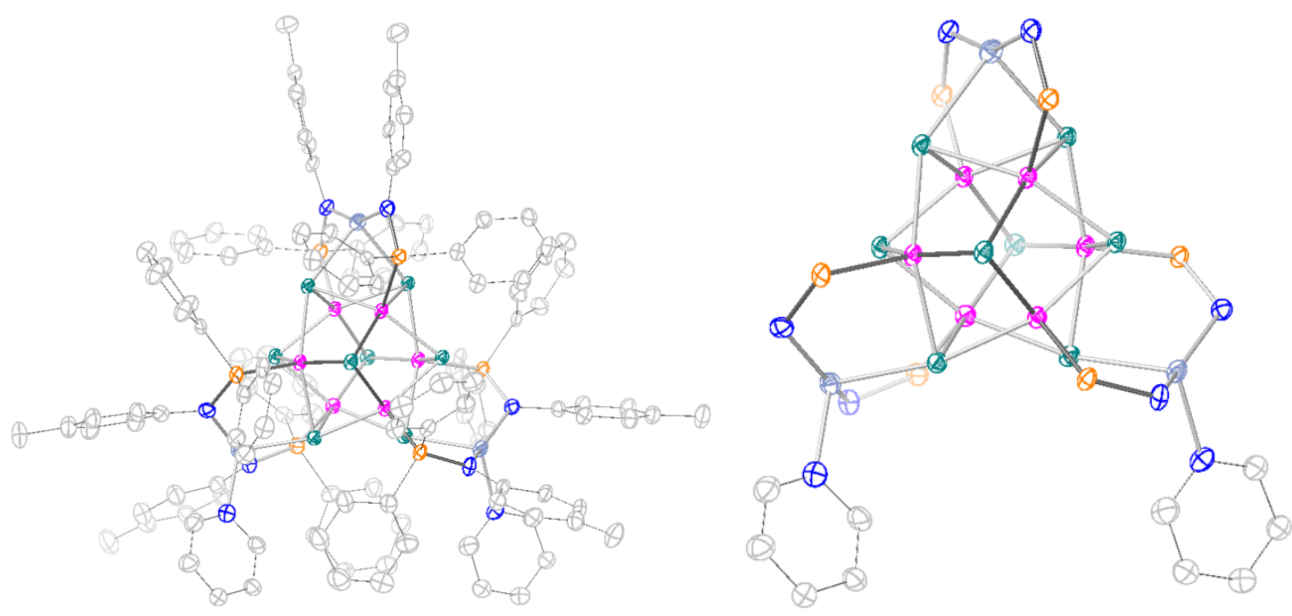

Figure S24. Molecular structure of 1-bipy with thermal ellipsoids shown at a 50\% probability level. Hydrogen atoms, disorder, and co-crystallized solvent molecules are omitted for clarity.

\section{S4.5 1-tpphz}

Dark red prismatic crystals were grown from the reaction mixture at room temperature over the course of one week. The unit cell contained disordered DCM solvent molecules which were removed with SQUEEZE. ${ }^{12-14}$ 


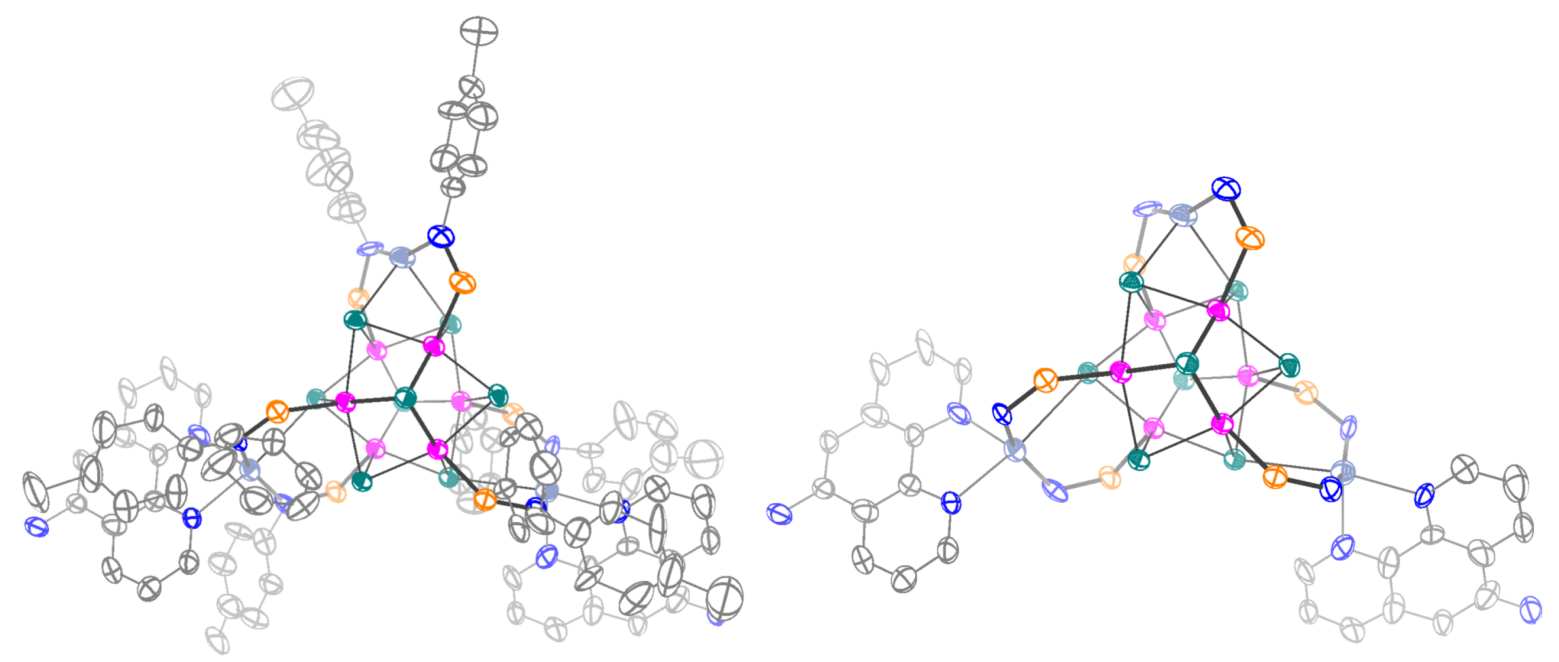

Figure S25. Structure of one 1-tpphz unit with thermal ellipsoids shown at a 50\% probability level.

\section{S4.6 2-bipy}

Data was collected at $-173^{\circ} \mathrm{C}$ on a Nonius Kappa CCD FR590 single crystal X-ray diffractometer, Moradiation. Small, dark red, prismatic crystals were grown from the reaction mixture at room temp over the course of 2 days. The contribution of about 18 disordered DCM solvent molecules per asymmetric unit to the diffraction pattern was removed with SQUEEZE ( $1563 \mathrm{eV}$ in voids). ${ }^{12-14}$ Two $\mathrm{PF}_{6}{ }^{-}$anions were found, where one of which appeared disordered. The structure required several constraints and restraints. All phenyls were optimized with AFIX 66 ... AFIX 0 loops. All complex motives aminophosphines were related with the SAME command. All pyridine halves of 4,4'-bipyridines were coupled with SAME. Pyridine moieties required FLAT restraints. Overall, an ISOR for carbons, nitrogen, and fluorine to prevent non-positive definite displacement matrices, and a DELU command including carbons, nitrogen and phosphorous were needed connecting the isotropic displacements along bonds. Some hydrogen atoms came slightly too close to each other which required their distances to be maintained with DFIX (since the data quality did not allow for a more detailed disorder model of phenyls and toluene) and 200 bad reflections were removed. While the small crystal size, the large unit cell (14771(12) $\left.\AA^{3}\right)$, and solvent disorder resulted in weak higher angle scattering, the structure is publishable, and the connectivity (and stoichiometry) is reliable.
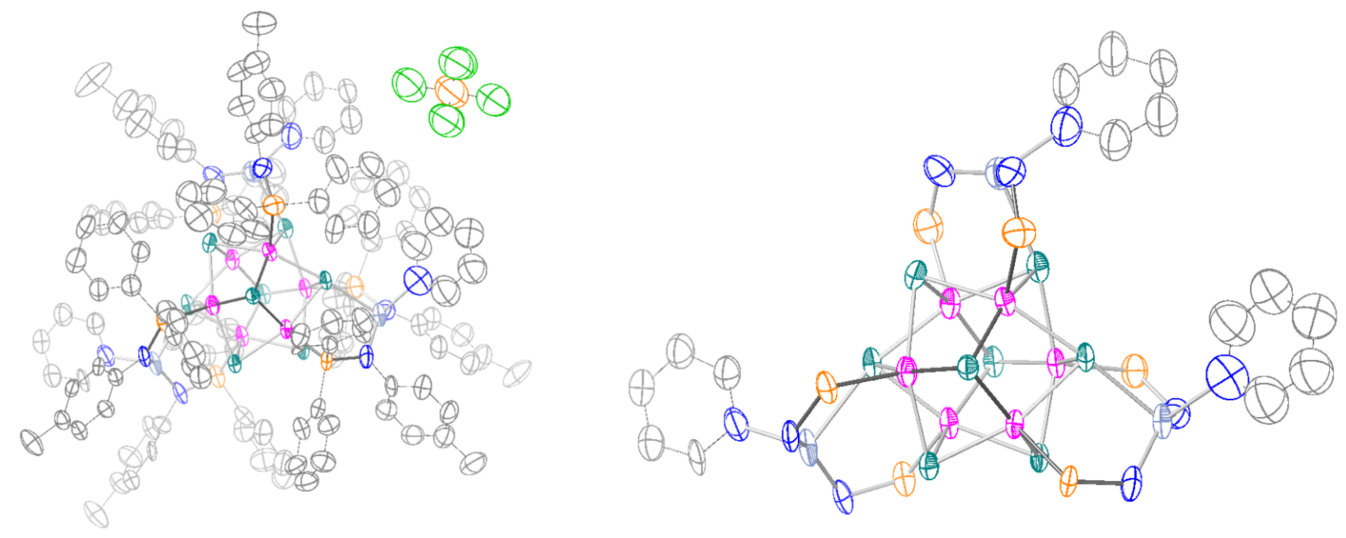

Figure S26. Structure of one $\mathrm{Zn}_{3}$ (bipy) 1.5 unit with thermal ellipsoids shown at a 50\% probability level. 


\section{S4.7 X-ray Structure Tables}

Table S2. Crystallographic data for $\mathbf{Z n}_{3}(\mathrm{THF})_{2}, \mathbf{Z n}_{3}(\text { phen })_{2}$ and $\left[\mathbf{Z n}_{3}(\text { phen })_{3}\right]\left[\mathrm{PF}_{6}\right]$

\begin{tabular}{|c|c|c|c|}
\hline Compound & $\mathbf{Z n}_{3}(\mathrm{THF})_{2} \cdot 2 \mathrm{THF}$ & $\mathbf{Z n}_{3}(\text { phen })_{2}$ & {$\left[\mathbf{Z n}_{3}(\text { phen })_{3}\right]\left[\mathrm{PF}_{6}\right] \cdot \mathrm{Et}_{2} \mathrm{O} \cdot 2 \mathrm{MeCN}$} \\
\hline CCDC number & 2102887 & 2102892 & 2102890 \\
\hline Empirical formula & $\mathrm{C}_{256} \mathrm{H}_{260} \mathrm{Co}_{12} \mathrm{~N}_{12} \mathrm{O}_{7} \mathrm{P}_{12} \mathrm{Se}_{16} \mathrm{Zn}_{6}$ & $\mathrm{C}_{138} \mathrm{H}_{118} \mathrm{Co}_{6} \mathrm{~N}_{10} \mathrm{P}_{6} \mathrm{Se}_{8} \mathrm{Zn}_{3}$ & $\mathrm{C}_{158} \mathrm{H}_{142} \mathrm{Co}_{6} \mathrm{~F}_{6} \mathrm{~N}_{14} \mathrm{OP}_{7} \mathrm{Se}_{8} \mathrm{Zn}_{3}$ \\
\hline Formula weight & 6351.12 & 3283.61 & 3765.01 \\
\hline Temperature $\left({ }^{\circ} \mathbf{K}\right)$ & $100(2)$ & $100(2)$ & $100(2)$ \\
\hline Wavelength (Å) & 0.71073 & 0.71073 & 0.71073 \\
\hline Crystal system & Monoclinic & Triclinic & Triclinic \\
\hline Space group & $\mathrm{P} 2{ }_{1} / \mathrm{c}$ & $\mathrm{P}-1$ & $\mathrm{P}-1$ \\
\hline $\mathbf{a}(\AA)$ & $23.165(4)$ & $16.5919(16)$ & $15.2771(8)$ \\
\hline $\mathbf{b}(\AA)$ & $19.118(3)$ & $18.8643(17)$ & $25.6348(14)$ \\
\hline c $(\AA)$ & $28.120(4)$ & $24.195(2)$ & $26.4908(13)$ \\
\hline$\alpha\left({ }^{\circ}\right)$ & 90 & $92.481(6)$ & $117.056(3)$ \\
\hline$\beta\left({ }^{\circ}\right)$ & $92.232(9)$ & $96.376(6)$ & $102.934(3)$ \\
\hline$\gamma\left({ }^{\circ}\right)$ & 90 & $102.106(6)$ & $95.533(3)$ \\
\hline Volume $\left(\AA^{3}\right)$ & $12444(3)$ & $7560.0(12)$ & $8766.7(8)$ \\
\hline $\mathbf{Z}$ & 2 & 2 & 2 \\
\hline$\rho^{\text {calc }}\left(\mathrm{g} \mathrm{cm}^{-3}\right)$ & 1.695 & 1.442 & 1.426 \\
\hline Absorption coefficient $\left(\mathrm{mm}^{-1}\right)$ & 3.818 & 3.144 & 2.736 \\
\hline$F(000)$ & 6328 & 3260 & 3758 \\
\hline Crystal size $\left(\mathrm{mm}^{3}\right)$ & $0.080 \times 0.070 \times 0.040$ & $0.230 \times 0.100 \times 0.020$ & $0.170 \times 0.100 \times 0.100$ \\
\hline Theta range for data collection $\left({ }^{\circ}\right)$ & 1.381 to 25.123 & 1.334 to 25.350 & 1.405 to 28.507 \\
\hline Index ranges & $-27 \leq \mathrm{h} \leq 27,-22 \leq \mathrm{k} \leq 22,-33 \leq \mathrm{l} \leq 33$ & $-19 \leq \mathrm{h} \leq 19,-22 \leq \mathrm{k} \leq 22,-30 \leq \mathrm{l} \leq 30$ & $-20 \leq \mathrm{h} \leq 20,-34 \leq \mathrm{k} \leq 34,-35 \leq \mathrm{l} \leq 35$ \\
\hline Reflections collected & 43602 & 131590 & 87063 \\
\hline Independent reflections & $22177[\mathrm{R}(\mathrm{int})=0.1891]$ & $27423[\mathrm{R}(\mathrm{int})=0.2127]$ & $43852[\mathrm{R}(\mathrm{int})=0.0463]$ \\
\hline Completeness to theta $=25.000^{\circ}$ & $99.8 \%$ & $99.3 \%$ & $99.8 \%$ \\
\hline Data / restraints / parameters & 22177 / 1255 / 1470 & $27473 / 544 / 1619$ & $43852 / 159 / 1890$ \\
\hline Goodness-of-fit on $\mathbf{F}^{2}$ & 1.012 & 1.009 & 1.021 \\
\hline Final $R$ indices $[\mathrm{I}>\mathbf{2} \operatorname{sigma}(\mathrm{I})]$ & $\mathrm{R} 1=0.1138, \mathrm{wR} 2=0.2526$ & $\mathrm{R} 1=0.0918, \mathrm{wR} 2=0.2106$ & $\mathrm{R} 1=0.0380, \mathrm{wR} 2=0.0782$ \\
\hline $\mathbf{R}$ indices (all data) & $\mathrm{R} 1=0.2375, \mathrm{wR} 2=0.3103$ & $\mathrm{R} 1=0.2344, \mathrm{wR} 2=02894$ & $\mathrm{R} 1=0.0731, \mathrm{wR} 2=0.0881$ \\
\hline Largest diff. peak and hole $\left(\mathrm{e}^{-} \AA^{-3}\right)$ & 1.856 and -1.603 & 1.379 and -1.170 & 0.945 and -0.860 \\
\hline
\end{tabular}


Table S3. Crystallographic data for 1-bipy, 2-bipy, and 1-tpphz

\begin{tabular}{|c|c|c|c|}
\hline Compound & 1-bipy $\cdot 4$ toluene & 2-bipy & 1-tpphz \\
\hline CCDC number & 2102891 & 2102888 & 2102889 \\
\hline Empirical formula & $\mathrm{C}_{311} \mathrm{H}_{292} \mathrm{Co}_{12} \mathrm{~N}_{16} \mathrm{P}_{12} \mathrm{Se}_{16} \mathrm{Zn}_{6}$ & $\mathrm{C}_{258} \mathrm{H}_{228} \mathrm{Co}_{12} \mathrm{~F}_{12} \mathrm{~N}_{18} \mathrm{P}_{14} \mathrm{Se}_{16} \mathrm{Zn}_{6}$ & $\mathrm{C}_{138} \mathrm{H}_{114} \mathrm{Co}_{6} \mathrm{~N}_{12} \mathrm{OP}_{6} \mathrm{Se}_{8} \mathrm{Zn}_{3}$ \\
\hline Formula weight & 6987.97 & 6604.89 & 3307.60 \\
\hline Temperature $\left({ }^{\circ} \mathbf{K}\right)$ & $100(2)$ & $100(2)$ & $100(2)$ \\
\hline Wavelength & 0.71073 & 0.71073 & 0.71073 \\
\hline Crystal system & Monoclinic & Triclinic & Triclinic \\
\hline Space group & P $21 / n$ & P -1 & $\mathrm{P}-1$ \\
\hline $\mathbf{a}(\AA)$ & $26.093(3)$ & $18.943(9)$ & $19.1661(16)$ \\
\hline b (Å) & $18.874(3)$ & $28.237(13)$ & 20.5691(16) \\
\hline c (Å) & $30.338(4)$ & $31.465(14)$ & $21.9034(18)$ \\
\hline$\alpha\left(^{\circ}\right)$ & 90 & $112.489(11)$ & $69.547(4)$ \\
\hline$\beta\left(\left(^{\circ}\right)\right.$ & $106.615(4)$ & $97.563(12)$ & $65.685(4)$ \\
\hline$\gamma\left({ }^{\circ}\right)$ & 90 & $102.224(12)$ & $86.539(4)$ \\
\hline Volume $\left(\AA^{3}\right)$ & $14317(3)$ & 14771(12) & $7337.6(11)$ \\
\hline $\mathbf{Z}$ & 2 & 2 & 2 \\
\hline$\rho^{\text {calc }}\left(\mathrm{g} \mathrm{cm}^{-3}\right)$ & 1.621 & 1.485 & 1.497 \\
\hline Absorption coefficient $\left(\mathrm{mm}^{-1}\right)$ & 3.325 & 3.234 & 3.240 \\
\hline $\mathbf{F}(000)$ & 6996 & 6536 & 3280 \\
\hline Crystal size $\left(\mathrm{mm}^{3}\right)$ & $0.220 \times 0.130 \times 0.050$ & $0.100 \times 0.050 \times 0.040$ & $0.140 \times 0.070 \times 0.070$ \\
\hline Theta range for data collection $\left({ }^{\circ}\right)$ & 1.286 to 28.565 & 0.828 to 25.027 & 1.502 to 25.027 \\
\hline Index ranges & $-34 \leq \mathrm{h} \leq 34,-25 \leq \mathrm{k} \leq 25,-40 \leq \mathrm{l} \leq 40$ & $-22 \leq \mathrm{h} \leq 22,-32 \leq \mathrm{k} \leq 32,-35 \leq \mathrm{l} \leq 35$ & $-22 \leq \mathrm{h} \leq 22,-24 \leq \mathrm{k} \leq 24,-26 \leq \mathrm{l} \leq 26$ \\
\hline Reflections collected & 133057 & 51575 & 50410 \\
\hline Independent reflections & $35562[\mathrm{R}(\mathrm{int})=0.1236]$ & $51575[\mathrm{R}(\mathrm{int})=0.2341]$ & $25882[\mathrm{R}(\mathrm{int})=0.1757]$ \\
\hline Completeness to theta $=25.000^{\circ}$ & $98.2 \%$ & $99.8 \%$ & $99.8 \%$ \\
\hline Data / restraints / parameters & $35562 / 1576 / 1686$ & 51575 / 6364 / 2614 & 25882 / 97 / 1575 \\
\hline Goodness-of-fit on $\mathbf{F}^{2}$ & 1.144 & 1.012 & 0.929 \\
\hline Final $R$ indices [I $>2$ sigma(I)] & $\mathrm{R} 1=0.1082, \mathrm{wR} 2=0.2726$ & $\mathrm{R} 1=0.1495, \mathrm{wR} 2=0.2958$ & $\mathrm{R} 1=0.0781, \mathrm{wR} 2=0.1631$ \\
\hline $\mathbf{R}$ indices (all data) & $\mathrm{R} 1=0.1508, \mathrm{wR} 2=0.2939$ & $\mathrm{R} 1=0.3551, \mathrm{wR} 2=0.4257$ & $\mathrm{R} 1=0.2194, \mathrm{wR} 2=0.2219$ \\
\hline Largest diff. peak and hole $\left(\mathrm{e}^{-} \AA^{-3}\right)$ & 2.533 and -1.776 & 2.131 and -1.378 & 1.258 and -1.033 \\
\hline
\end{tabular}




\section{S5 References}

(1) Kephart, J. A.; Mitchell, B. S.; Chirila, A.; Anderton, K. J.; Rogers, D.; Kaminsky, W.; Velian, A. Atomically Defined Nanopropeller Fe3Co6Se8(Ph2PNTol)6: Functional Model for the Electronic Metal-Support Interaction Effect and High Catalytic Activity for Carbodiimide Formation. J. Am. Chem. Soc. 2019, 141 (50), 19605-19610. https://doi.org/10.1021/jacs.9b12473.

(2) Chavan, H. V.; Adsul, L. K.; Bandgar, B. P. Polyethylene Glycol in Water: A Simple, Efficient and Green Protocol for the Synthesis of Quinoxalines. J. Chem. Sci. 2011, 123 (4), 477-483. https://doi.org/10.1007/s12039-011-0081-8.

(3) Wachter, E.; Moyá, D.; Parkin, S.; Glazer, E. C. Ruthenium Complex "Light Switches" That Are Selective for Different G-Quadruplex Structures. Chemistry - A European Journal 2016, 22 (2), 550 559. https://doi.org/10.1002/chem.201503203.

(4) Bruker APEX2 (Version 2.1-4), SAINT (Version 7.34A), SADABS (Version 2007/4), 2007 BrukerAXS Inc, Madison, Wisconsin, USA.

(5) Sheldrick, G.M. Acta Cryst. 2015 A71, 3-8.

(6) Altomare, A.; Burla, C.; Camalli, M.; Cascarano, G. L.; Giacovazzo, C.; Guagliardi, A.; Moliterni, A.G.G.; Polidori, G.; Spagna, R. J. Appl. Crystallogr., 1999, 32, 115-119.

(7) Altomare, A.; Cascarano, G. L.; Giacovazzo, C.; Guagliardi, A. J. Appl. Crystallogr., 1993, 26, 343350 .

(8) Sheldrick, G. M. SHELXL-97, Program for the Refinement of Crystal Structures, 1997, University of Göttingen, Germany.

(9) Sheldrick, G. M. Acta Cryst. 2015, C71, 3-8.

(10) Mackay, S.; Edwards, C.; Henderson, A.; Gilmore, C.; Stewart, N.; Shankland, K.; Donald, A. MaXus: A Computer Program for the Solution and Refinement of Crystal Structures from Diffraction Data, 1997, University of Glasgow, Scotland.

(11) Waasmaier, D.; Kirfel, A. Acta Cryst., 1995, 51, 416-430.

(12) Spek, A. L. Single-Crystal Structure Validation with the Program PLATON. J Appl Cryst 2003, 36 (1), 7-13. https://doi.org/10.1107/S0021889802022112.

(13) Spek, A. L. Structure Validation in Chemical Crystallography. Acta Cryst D 2009, 65 (2), 148-155. https://doi.org/10.1107/S090744490804362X.

(14) van der Sluis, P.; Spek, A. L. BYPASS: An Effective Method for the Refinement of Crystal Structures Containing Disordered Solvent Regions. Acta Cryst A 1990, 46 (3), 194-201. https://doi.org/10.1107/S0108767389011189. 